Aapg Bulletin

April 2016, Volume 100 Issue 4 Pages 565-595

Achimer

http://dx.doi.org/10.1306/02011613196

http://archimer.ifremer.fr/doc/00319/42985/

(C) 2016. The American Association of Petroleum Geologists. All rights

reserved.

\title{
A Pliocene-Quaternary analogue for ancient epeiric carbonate settings: The Malita intrashelf basin (Bonaparte Basin, northwest Australia)
}

\author{
Courgeon Simon ${ }^{1,{ }^{*}}$, Bourget Julien ${ }^{2,{ }^{*}}$, Jorry Stephan ${ }^{1,{ }^{*}}$ \\ ${ }^{1}$ French Res Inst Exploitat Sea, Dept Marine Geosci, F-29280 Plouzane, France. \\ ${ }^{2}$ Univ Western Australia, Sch Earth \& Environm, Ctr Energy Geosci, 35 Stirling Hwy, Crawley, WA \\ 6009, Australia.
}

Corresponding authors: email addresses : simon.courgeon@gmail.com ; julien.bourget@uwa.edu.au ; stephan.jorry@ifremer.fr

\begin{abstract}
:
During the Plio-Quaternary, the Bonaparte Basin is characterized by a very wide (>600 km, >370 mi) carbonate platform and $200 \mathrm{~km}$-wide (125 mi-wide) intra-shelf basin (the Malita ISB). Using 3D and 2D seismic data combined with exploration well data, this study characterizes the stratigraphic evolution of the Malita ISB during the last 3.5 million years. Two third-order transgressive sequences can be distinguished. A late Pliocene transgression occurred over an irregular topography resulting from the flexural reactivation of the Malita graben. In the centre of the intra-shelf basin, carbonate aggradation resulted in the formation of isolated carbonate platforms separated by deeper water seaways and interplatform areas. Wider and more numerous carbonate platforms developed on the edges of the intrashelf basin. During the late Quaternary, renewed flexural deformation initiated a second transgressive cycle marked by higher subsidence rates in the ISB centre than along its edges. High rates of accommodation creation (at third-order) combined with higher-frequency (fourth-order), high-amplitude fluctuating sea levels and increased clastic input resulted in the progressive demise and burial of the carbonate platforms in the ISB centre. Thus, the Plio-Quaternary stratigraphic architecture of the Malita ISB is strongly controlled by differential subsidence that controls spatial distribution of accommodation and ultimately platforms architectures. The Malita ISB constitute a rare recent analogue for Paleozoic and Mesozoic hydrocarbon-bearing intra-shelf basins.
\end{abstract}




\section{ACKNOWLEDGEMENTS}

23 We wish to thank TOTAL E\&P, TOTAL E\&P Australia and FUGRO for their support and for providing the seismic datasets used in this study. Special thanks to Eric Cauquil (TOTAL E\&P) and Julian Mather (TOTAL E\&P Australia) who greatly facilitated these exchanges. This collaborative project between IFREMER and the University of Western Australia was 27 funded through a LabexMER scholarship (ANR-10-LABX-19-01) and a UWA-RCA grant. We are also grateful to the sponsors of the UWA Reservoir Management(UWA:RM) research consortium for supporting this research.We are grateful to IHS and dGB Earth Sciences for providing academic licenses of their Kingdom and OpendTect software, respectively. We also insightful and constructive comments on earlier versions of this manuscript. 
Epeiric carbonate platform systems are made of laterally extensive (100-1000s km

wide) epicontinental shallow seas deposits (Pratt and James, 1986; Alsharhan and Nairn, 1993; Droste, 2010). These very wide shelves were frequently characterized by the development of an intra-shelf basin (ISB), such as Mesozoic carbonate platforms of the Arabian plate (Droste, 1990; Van Buchem et al., 2002; Droste and Steenwikel, 2004; Droste 2010; Van Buchem et al., 2010). ISBs are short-lived, shallow ( $<200 \mathrm{~m}$ deep) sedimentary sub-basins, generally less than several hundred kilometres in width (Burchette and Wright, 1992). They preferentially developed across tectonically stable areas such as passive margins and cratonic interior basins associated with low subsidence rates (Burchette and Wright, 1992; Grover, 1993; Droste, 1990; Droste 2010). Very wide continental shelves and epeiric seas are commonly found throughout Earth's history and much of the pre-Jurassic marine sedimentary rocks were deposited in such setting (Allison and Wells, 2006). Several mechanisms are involved in the formation of intra-shelf basins such as subtle tectonic movements (e.g. isostatic sagging) and/or differential aggradation of carbonate platforms (Droste, 1990; Burchette and Wright, 1992; Razin et al., 2010). ISBs are commonly fringed and overlain by carbonate accumulation and finally filled by fine-grained sediments (Burchette and Wright, 1992; Grover, 1993). Current stratigraphic and architectural models of intra-shelf basins are mainly derived from outcrop and seismic data of the Mesozoic Arabian platforms which are associated with very prolific petroleum systems (Markello and Read, 1982; Droste, 1990; Van Buchemet al., 2002; Droste and Steenwikel, 2004; Droste, 2010). In this setting, ISBs are commonly initiated by the deposition of organic-rich sediment layers accumulating under anoxic conditions (Droste, 1990; Grover, 1993; Elmore et al, 2012). During the following stages of evolution, the Arabian ISBs are marked by the aggradation and progradation of 
carbonate platforms that typically form large and good-quality hydrocarbon reservoirs, immediately overlying potential source-rocks (Droste, 2010). The demise of carbonate production is commonly associated with terrigenous or evaporitic basin fill sediments that can form excellent low-permeability seals (Burchette and Wright, 1992; Al Emadi et al., 2009; Droste, 2010). However, the stratigraphic evolution of ISBs appears to be sensitive to numerous parameters such as rates of rise in relative sea level(Burchette and Wright, 1992; Razin et al., 2010), distance to the coast (Grover, 1993) and terrigenous input from the continent (Droste, 1990; Grover, 1993, Droste 2010). Carbonate platforms bounding intrashelf basins can also be associated with widespread fluvial and tidal incisions, developing in different stratigraphic context along $4^{\text {th }}$ to $3^{\text {rd }}$-order timescales (Grelaud et al., 2010; Droste, 2010). These channelized systems can be observed in outcrop analogues and 3D seismic data in the Cretaceous of Oman and form significant heterogeneities at the reservoir-scale (Grelaud et al., 2010).Very wide continental shelves $(>300-400 \mathrm{~km})$ are rare in present days and there are currently no modern analogues of intra-shelf basins and their associated sedimentary processes from which architectural and stratigraphic models derived from fossil systems can be unravelled (Irwin, 1965; Burchette and Wright 1992; Wright and Burchette, 1996; Schlager 2005; Allison and Wells, 2006).

The aim of this study is to investigate the architecture and stratigraphic evolution of the Plio-Quaternary Malita ISB that developed along the Bonaparte continental shelf in NW Australia (Bourget et al., 2012). The study uses a large 3D seismic dataset to (1) describe and understand the processes of onset, growth, and demise of shallow water carbonates that accumulated in the Malita ISB during the Plio-Quaternary; (2) characterize the geometries of depositional elements (carbonate platforms and build-ups, tidal and fluvial channels) found in an intra-shelf basin setting, and to describe their stratigraphic significance, and, (3) propose a $3^{\text {rd }}$ and $4^{\text {th }}$-order stratigraphic model for the evolution of the Malita ISB, by integrating 
seismic stratigraphic results with well-constrained paleo-environmental data of the PlioQuaternary.

\section{REGIONAL SETTING}

\section{Tectono-stratigraphy}

The Bonaparte Basin is the northernmost sedimentary basin of the NW Australian continental shelf (Fig.1B) and contains up to $15 \mathrm{~km}$ of Phanerozoic sediments (Longley et al. 2002). This basin extends over an area of approximately $270,000 \mathrm{~km}^{2}$ for a modern distance of $615 \mathrm{~km}$ from the coast to the shelf-edge (Bourget et al. 2012). The Bonaparte Basin is divided into several Paleozoic and Mesozoic sub-basins and platforms formed during different phases of extension and compression (Veevers, 1971; Patillo and Nicholls, 1990; O'Brien, 1993, Baillie et al., 1994; O 'Brien et al., 1996; Whittam et al., 1996; Shuster et al., 1998; Keep et al., 2000; Longley et al., 2002; Frankowicz and McClay, 2010). The Bonaparte Basin was initiated during Paleozoic phases of continental break-up followed by a Triassic compressive event (O'Brien 1993; Shuster et al., 1998; Longley et al., 2002; Frankowicz and McClay, 2010). The present continental margin started to develop during a mid-Jurassic to Early Cretaceous NW-SE extension (Baillie et al., 1994; Shuster et al., 1998; Longley et al., 2002; Frankowicz and McClay, 2010) that initiated the major depocenters including the Malita Graben (O'Brien et al., 1996; Shuster et al., 1998; Harrowfield et al., 2003).

The most recent phase of tectonic activity in the Bonaparte Basin started during the late Miocene (Keep et al., 2000; Langhi et al., 2011; Saqab and Bourget, 2015). This phase of deformation coincides with the onset of collision between the Australian plate and the Banda Arc (Fig. 1B) which resulted in the development of lithospheric flexure on the northern 
Australian margin (Veevers, 1971; Shuster et al., 1998; Keep et al., 2000; de Ruig et al., 2000; Keep and Haig, 2010; Langhi et al., 2011; Bourget et al., 2012; Haig, 2012; Haig and Bandini, 2013; Saqab and Bourget, 2015). In the central part of the Bonaparte shelf, flexure resulted in the reactivation of the Malita Graben with renewed subsidence in its centre and extensional faulting mostly restricted along its edges (Bourget et al., 2012). This resulted in the formation of a large intra-shelf basin associated with a subtle differential topography and very gentle slope gradients $\left(<0.1^{\circ}\right)$, where up to $270 \mathrm{~m}$ of Quaternary sediments accumulated (Bourget et al., 2012). Nowadays, the shallow $(<200 \mathrm{~m})$ Bonaparte continental shelf is separated from the Timor Island by the narrow $(<15 \mathrm{~km}$ wide) and deep (up to $3500 \mathrm{~m}$ depth) Timor trough. The current convergence rate of the Australian plate (Fig.1B) is estimated about $7-8 \mathrm{~cm} / \mathrm{yr}$ (Kreemer et al., 2000).

\section{Modern shelf sedimentation and hydrodynamics}

The present-day Bonaparte continental shelf is up to $630 \mathrm{~km}$ wide (south to north) and over $1500 \mathrm{~km}$ in lateral extent (east to west; Fig. 1A). Carbonate platforms at 30-70 m water depth compose most of the shallow water areas of the continental shelf (Fig. 1A). The platform sediments are composed by carbonate sand and gravel with abundant corals, Halimeda, sponges, and marine mollusks (Van Andel and Veevers, 1967; Anderson et al., 2011). Large isolated reef build-ups and carbonate shoals develop along both the eastern (Anderson et al., 2011) and western shelf-margins (Saqab and Bourget, 2015; Fig. 1A). In the center of the continental shelf, the Malita ISB forms a 150-200 km wide (from west to east), low gradient $\left(0.03-0.07^{\circ}\right)$ depression that reaches 130 to $140 \mathrm{~m}$ water depth in its centre. Towards the north, it narrows to approximately $80 \mathrm{~km}$ in width, the slope gradient steepens $\left(0.1-0.2^{\circ}\right)$, and maximum depths reach $220 \mathrm{~m}$ below sea-level. This area corresponds to the 
transition to the Malita Valley, a $<10 \mathrm{~km}$-wide shelf channel connecting the ISB to the Timor Trough across the shelf-margin. In the present-day, about $196^{*} 10^{6}$ tons of terrigenous sediment are delivered each year by the fluvial catchments to the Malita ISB (Lees, 1992). However, active carbonate platform growth still occurs along the shallowest parts of the platforms bounding the ISB (Anderson et al., 2011). At present, the Bonaparte Basin is a semi-diurnal macrotidal environment with a mean spring range of $+/-8 \mathrm{~m}$ at the shoreline and +/- 2 m close to the shelf-edge (Anderson et al., 2011). Modern tides create current velocities of $0.45 \mathrm{~m} . \mathrm{s}-1$ measured within $\sim 100 \mathrm{~m}$ deep valleys at the eastern shelf-edge (Anderson et al., 2011).

\section{DATA AND METHODS}

The seismic data used in this study consists of a 3D seismic dataset (Malita 3D; Fig.1A; Fig.2) provided by TOTAL E\&P Australia. The processed data represents 480 traces per record, with a sample interval of $2 \mathrm{~ms}$ and a trace length of $1600 \mathrm{~ms}$. It covers an area of $2320 \mathrm{~km}^{2}$ and presents an inline and crossline spacing of $25 \mathrm{~m}$ and $6.25 \mathrm{~m}$ respectively, which results in a high spatial resolution (2300 inlines oriented W-E and 15250 crosslines oriented $\mathrm{N}-\mathrm{S}$ ). The TWT time window available extends from $0 \mathrm{~s}$ to $1.5 \mathrm{~s}$. Stratigraphic data is derived from biostratigraphic and palynological analysis (Rexilius and Islam, 1985) compiled in the publicly available completion report of Darwinia-1A (Fig.1A) exploration well. The conventional 2D seismic data used to correlate the well data with the 3D seismic survey was obtained from Geoscience Australia (Fig.1A).

Seismic interpretation and horizon picking were conducted on the IHS Kingdom ${ }^{\mathrm{TM}}$ Software using both manual and auto-tracking tools. Grids were computed with the Flex Gridding algorithm and are derived from horizons interpreted every 10 to 20 inlines. Seismic 
interpretation was conducted based on the seismic stratigraphy methodology (Mitchum et al., 1977) which consists in (1) defining the seismic facies, characterized by their signal properties (continuity, amplitude, and frequency), their internal configuration and external geometry; (2) tracking the seismic reflections and associated reflection (stratal) terminations, and; (3) describing the geometries of the seismic reflections within the depositional units bounded by these seismic discontinuities. Seismic data were further analysed by extracting reflection amplitude and other seismic attributes along a narrow (+/- $5 \mathrm{~ms}$ TWT) time window around the interpreted and gridded horizons and by using time slices of the seismic volume. Three different types of seismic attributes were calculated with the algorithms available in dGB's OpendTect ${ }^{\mathrm{TM}}$ software: (1) Root Mean Square amplitudes (RMS); (2) Similarity (equivalent to a coherency attribute). These attributes allow characterizing the seismic geomorphology of the various stratigraphic units and aided picking faults in the study area. Observation of the geomorphic features on horizontal displays also allowed identifying buried landforms which were then compared to modern analogues (e.g., seismic geomorphology; Davies et al., 2007; Posamentier et al., 2007).

\section{SEISMIC STRATIGRAPHY}

\section{Seismic facies and stratal discontinuities}

Five main seismic facies (Fig.3) were observed in the seismic data of the Malita ISB. F1a and F1b both present moderate to low amplitudes, a general wavy internal configuration (Fig. 3) and are overall observed within mound-shape to flat-topped depositional features (Fig. 4 \& 5) capped by strong and positive-amplitude reflections. F1a corresponds to horizontal to sub-horizontal, discontinuous and generally low amplitudes seismic reflections 
mainly located in the center of the mound-shaped depositional features (Fig. 3, 4A \& 5A). F1b corresponds to oblique, low to moderate amplitude seismic reflections characterized by a wedge-shape external geometry and usually located on the edges of the mound-shaped depositional features (Fig. 3, 4A\& 5A). F2a and F2b both correspond to moderate to high amplitude seismic facies, associated with channel-shaped to wavy geometries (Fig. 3). F2b corresponds to wavy to subparallel and semi-continuous to continuous internal reflections (Fig. 3) associated with large (500-4000 m wide) channel-shaped geometries laterally bounded by the seismic facies F1a or F1b (Fig. 3, 4 \& 5). In contrast, the facies F2a consists of semi-continuous reflections associated with smaller (ten's of meters to $2.5 \mathrm{~km}$ wide) channelized reflections and laterally, to wavy and sheet geometries (Fig. 3, 4 \& 5). Facies F3 shows high continuity, parallel to sub-parallel reflections with very rare channelized shapes and moderate to high amplitudes (Fig. 3). Reflections within this seismic facies locally onlap and partly overly the mound-shape to flat-top depositional features constituted by the seismic facies F1a and F1b (Fig. 4 \& 5).

F1a and F1b seismic facies present geometrical (mound-shape to flat-top, constructional) and geophysical (low amplitudes, chaotic to wavy configurations) characteristics of carbonate platforms deposits (e.g. Bachtel et al., 2004, Burgess et al., 2013). Seismic reflections of F1a are vertically stacked and this facies is thus interpreted as the result of carbonate aggradation. The oblique internal reflections of F1b suggest that this seismic facies results from carbonate sediments prograding into the inter-platform areas through bioconstruction and/or downslope shedding of platform debris (e.g. Hine et al., 1992; Fig. 3). F2a and F2b are interpreted as sedimentary accumulations dominated by various channels networks and associated deposits (Fig. 3). These will be further detailed and interpreted in the Seismic Geomorphology section of this paper. Seismic facies F3 is interpreted as basinal sheet-like deposits. 
Two main seismic unconformities were identified (Fig. 4, 5\& 6). These correspond to prominent seismic reflections that can be consistently interpreted across the $3 \mathrm{D}$ volume. They are associated with upper and/or lower stratal terminations, and mark changes in depositional geometries. D1 is highlighted by erosional truncations in the underlying reflections (Fig 4). The interpretation of D1 is locally affected by significant velocity pull-ups (Fig.4 \& 6) due to the high internal velocities of the overlying carbonate bodies (seismic facies F1a and F1b) and the seabed multiple. Locally, D1 marks a distinct vertical change of seismic facies, from higher amplitude, sub parallel and contorted to disrupted and slightly chaotic reflections to mound-shaped and moderate to low amplitudes reflections(seismic faces F1a and b; Fig. 3). The seismic unconformity D2 is highlighted by a very high-amplitude reflector capping some of the mound-shape to flat-top features (Fig.4 \& 5). Between these geometries, D2 is also associated with a vertical change in seismic facies, from F2a-b (below D2) to F3 (above D2) (Fig. 4\& 5). D2 is also associated with upper onlap terminations and basal truncations (Fig.4 \& 5). Above D2, a third seismic unconformity (D3) can be defined on the basis of upper onlap terminations (Fig.4 \& 5). D3 is associated with associated a highly continuous and strong amplitude reflection that can be tracked consistently through the $3 \mathrm{D}$ volume. However, it is not associated with a significant change in seismic facies and reflectors configuration.

\section{Depositional Units}

D1, D2 and the seafloor are bounding two depositional units (Unit A and Unit B, Fig. 4B, 5 \& 6) which show different internal reflection geometries. The stratigraphic architecture of each of these units is here investigated using a combination of $2 \mathrm{D}$ and $3 \mathrm{D}$ seismic stratigraphy (Fig. 4-9). 
The oldest depositional unit (Unit A) is bounded by D1 and D2 (Fig. 4B, 5 \& 6). Unit

253

A is dominated by wavy and chaotic reflections (F1a, Fig. 3) horizontally stacking and leading to the formation of 3-15 km wide and 30-90m high flat-top and mounds-shape morphologies (Fig. 4, 6, 7B, 8A \& 9A). The peripheries of these morphologies are marked by minor inclined shingling reflections (F1b, Fig. 3, 4 \& 5). Downward, wedge shape reflections (F1b, Fig. 3) are thinning out away from these low amplitude seismic geometries (Fig. $4 \& 5$ ). Seismic facies F2a, F2b and F3 are observed laterally and in between the mound-shape and flat-top morphologies (Fig.4 \& 6).

\section{Interpretation}

Unit A is dominated by aggrading mound-shape and flat top features interpreted as growing carbonate platforms. They are dominated by aggrading geometries (F1a) with minor progradations (F2b). Seismic data suggest that carbonate growth focused above apparent paleo-topographic highs below D1 (Fig. 4, 5 \& 6). However, the topography of these highs is exaggerated by the velocity pull-ups caused by the overlying carbonate platforms (Fig. $6 \&$ 7), and these could largely be seismic artefacts. The carbonate platforms are mostly distributed along the western fringe of the intra-shelf basin (Fig. $6 \&$ 9A), and are less numerous (and narrower) in the area corresponding to the deepest part of the intra-shelf basin at present-day. 3D seismic data show that the carbonate platforms rapidly developed above D1 and reached their maximum size (in width) just below the D2 unconformity (Fig. 7, 8A \& 9A). Significant aggradation also occurs in between the carbonate platforms and in the basin center where seismic facies F2a, F2b and F3 are observed (Fig. 4, 5 \& 6). However, the paleotopography observed along D2 (Fig. 4,6 \& 8A) shows that by the end of Unit A the carbonate platforms raised significantly $(30-90 \mathrm{~m})$ above the surrounding platform and basin areas. 
The youngest depositional unit (Unit B) is bounded between the seismic unconformity D2 and

277 the seafloor (Fig. 4B, 5 \& 6). Seismic facies F3 dominates in Unit B (Fig. 4, 5 \& 6). These

278 moderate to high amplitude, continuous seismic reflections onlap and locally overlain the carbonate platforms of Unit A (Fig. 4, 5 \& 6). Above D2, the aggrading seismic reflections of F1a are still observed locally and form $0.5-4 \mathrm{~km}$ wide isolated mound-shape geometries interpreted as small carbonate build-ups (Fig. 4, 5 \& 6) whose sizes decrease towards the seafloor (Fig. 5). Seismic data suggest that these build-ups initiate above the highest topography of the underlying platforms (Figs. 4, $5 \& 8$ ). However, this could be an artefact caused by velocity pull-ups (Fig. $4 \& 5$ ).

\section{Interpretation}

Overall, Unit B is marked by a strong reduction of the size and distribution of the carbonate platforms (F1a and F1b) that were dominant in Unit A. This reduction mainly occurs through a rapid and important retrogradation of the platform margins (Fig. 4, $5 \& 8$ ). Thus, D2 is interpreted as the onset of a major backstepping phase (retrogradation of carbonate platform margins; e.g. Schlager et al., 2005) and local drowning of antecedent carbonate platforms (Fig. 5, $8 \&$ 9). This is particularly observed in the Malita ISB center, where drowned carbonate deposits are progressively buried by basinal, sheet-like deposits (seismic facies F3). Above D2, carbonate growth become restricted to small isolated buildups aggrading above the underlying platforms (Fig. $8 \& 9$ ). In between these build-ups, the seismic facies F2a and F2b (dominated by channelized geomorphologies in cross-sections) are no longer observed (Fig.4 \& 5). At the scale of the intra-shelf basin (Fig.9), Unit B seems to be characterized by a highly heterogeneous distribution of carbonate growth, with limited growth in the deeper-water ISB centre and higher growth rates along the shallow-water edges 
of the ISB, to the NW (Fig.6 \& 9B). This trend is supported by the present day configuration of the intra-shelf basin, with small and drowned carbonate build ups in the ISB centre and large and active platforms along its shallow-water edges (Anderson et al., 2011; Fig. 2, 6 \& 9B).

\section{Well data: lithology and age constraints}

The exploration well Dawinia-1A was drilled on the eastern edge of the intra-shelf basin (Fig.1A). It was correlated to the Malita 3D seismic volume using four regional 2D seismic lines (Fig. 10). Wireline log data (Fig.11) were calibrated by stratigraphic and lithological data obtained from well cuttings (Rexilius and Islam, 1985). Time-depth correlation data (obtained from the seismic velocity survey data of Darwinia-1) allowed tying the well data to the 2D seismic profiles. Well data indicates that Early Pliocene siliciclastic deposits are overlain by $\sim 250 \mathrm{~m}$ of younger limestones (Fig. $10 \& 11$ ). This indicates that the interval investigated in this study corresponds to strata younger than the Early Pliocene (Rexilius and Islam, 1985). The onset of carbonate deposition at a depth of $337 \mathrm{~m}$, which is associated with an abrupt shift of the gamma-ray log (Fig. 11), correlates with the seismic unconformity D1 (Fig. 10). The abrupt change from siliciclastic to carbonate deposition above D1 on well data is interpreted as the onset of carbonate platform growth in the Malita ISB, consistent with the geometries observed on seismic data above D1 (Fig. 4, 5 \& 6). These stages of establishment generally occur during a periods of relative sea-level rise (e.g., "start-up phase", Emery and Myers, 1996; Schlager, 2005). Biostratigraphic analysis of a sample located $30 \mathrm{~m}$ below D1 yields a calcareous nanoplankton subdivision NN15 (Rexilius and Islam, 1985), corresponding to a latest Early Pliocene age (Martini, 1971). Given the abrupt change from siliciclastic to carbonate lithologies seen in both gamma-ray and well cutting data along D1, 
and knowing that the Late Pliocene transition (ca. 3.5 Ma BP) corresponds to a period of rapid sea level rise following a major sea level lowstand (Miller et al., 2005), D1 is interpreted as the base of the Late Pliocene. The overlying unconformities D2 and D3 could not be correlated to clear, abrupt changes in gamma ray log (Fig.11). Moreover, the skeletal limestone samples recovered above D1 lack of age-diagnostic benthic foraminifera and are barren of calcareous nanoplankton and planktonic foraminifera (Rexilius and Islam, 1985) so there are no age constraints for D2 and D3.

\section{SEISMIC GEOMORPHOLOGY}

Seismic amplitude variation observed on interpreted horizons within Units A and Unit B allows investigating the depositional architecture and geometries within each depositional unit (Fig. 12, 13, 14 \& 15). Investigating the seismic geomorphologies associated with the seismic unconformities D2 and D3 (Fig. 16, $17 \& 18$ ) also help understanding the processes at the origin of their formation. The analysis show that Unit A, Unit B and the two seismic unconformities D2 and D3 are all associated with widespread and various (in nature and dimensions) channelized systems. Overall, the orientation of these features indicates a SSW -

NNE trend in the central, deepest part of the ISB, and a SE-NW to S-N trend in the western part of the study area (Fig.9).These trends remain stable throughout the Plio-Quaternary and are also consistent with the modern channel trends connecting the intra-shelf basin to the shelf-margin (Fig. 1). Seismic attributes show that there are three main types of channelized features.

- Type 1 -Inter-platform Seaways: in plan view, these features form 0.5 to $4 \mathrm{~km}$ wide seismic anomalies forming areas of generally higher seismic amplitudes between carbonate platforms (Fig. 7B \& 13). In cross-section these features are associated with the seismic facies 
F2b (Fig. 3), showing a generally aggrading, channelized to sheet-like internal fill (Fig. 4, 5 \& 12). Seismic data show that these areas of higher amplitude remain in a stable position throughout the stratigraphic evolution of the intra-shelf basin (Fig. 4, $9 \& 13$ ). These features are interpreted as inter-platform seaways, confined between the growing carbonate platforms of Unit A. The inter-platform seaways are associated with a complex internal architecture suggesting repeated incisions and filling phases (seismic facies F2b; Fig. 3, 4 \& 12). Seismic attribute maps also show the presence of smaller incisions forming along the paleo-valley floor of the seaways (Fig. 7B, 8A \& 13). Inter-platform seaways are commonly observed along modern and ancient carbonate settings (e.g. Eberli and Ginsburg, 1987; Bachtel et al., 2004; Posamentier et al., 2010). They represent corridors of increased tidal current velocity confined in between the high-relief carbonate topographies (Posamentier et al., 2010). Similarly, the large inter-platform seaways observed in the Malita ISB are interpreted as areas of increased, possibly tide-driven current velocities in between the carbonate platforms of Unit A. The seaways do not significantly change in width through times (Fig. $12 \& 13$ ). In the study area, the seaways become almost completely filled with sediments in Unit B (Fig. 12), as most carbonate platforms of the ISB centre get progressively buried. However, modern bathymetry show that the larger seaways draining through the shallow platforms along the edges of the ISB (e.g., the Malita and Lambert valleys; Fig. 1) remain active at present-day.

- Type 2 -Tidal channel networks: this second type of channelized features are only observed in Unit A. On seismic data they correspond to densely channelized systems typically composed by a large (1-2.5 $\mathrm{km}$ wide, and $<20 \mathrm{~m}$ deep), low to moderate-sinuosity channels (labelled main tidal channels" in Figure $14 \& 15$ ) fed by a dense network of tributaries showing complex and varying geomorphologies. These correspond to the seismic facies F2a (Fig. 3). The main valleys are found incising the inter-platform seaways (Fig. 13) and/or along the basin floor in the ISB center (Fig. 13, $14 \& 15$ ). The smaller tributaries feeding 
them show variable dimensions $(40-200 \mathrm{~m}$ wide and $<15 \mathrm{~m}$ deep, or below the vertical resolution of seismic data; (Fig. 15). These channels are associated with heterogeneous internal amplitudes indicating a complex cut \& fill history and cross-cutting relationships, hence suggesting these could be shorter-lived features compared to the inter-platform seaways (Facies F2a, Fig. 3, 4, 14 \& 15). Tributary channels are organized in meandering dendritic networks, elongate dendritic networks, complex tributary networks and interconnected tributaries (sensu Pye and French, 1993 and Hughes, 2012). The range and diversity of channel plan form shapes, sizes and sinuosities, in addition to the high density of channelization observed within the attribute maps of Unit A are typical features of tidal channel networks (Fagherazzi and Furbish, 2001; Hughes, 2012). The geomorphologies described above are comparable with modern tidal flats geomorphologies (Hughes, 2012) including the carbonate tidal flats of the Bahamian archipelago (Rankey and Berkeley, 2011; Berkeley and Rankey, 2012). At places, interconnected channel geometries are separated by $\mathrm{km}$-scale sub-circular to elongated zones of variable seismic amplitudes (Fig. 15). On seismic vertical sections, they are characterized by low amplitude reflections (Fig. 4A). Some of these areas are drained by narrow tributaries and/or formed in abandoned channel courses (Fig. 15). Their size varies from $30 \mathrm{~m}$ to up to $2 \mathrm{~km}$ wide (Fig. 15), and they are interpreted as tidal ponds (Rankey and Morgan, 2002). Overall, these complex channelized networks suggest that extensive tidal flat environments (at intertidal water depths) episodically developed in the topographic lows and basin floor areas in between the carbonate platforms of Unit A, i.e., during lower sea levels.

- -Fluvial-dominated channels: these channelized geomorphologies range from low to moderate-sinuosity individual channels to meandering channel belts (Fig. 16, 17, 18 \& 19B). Most of those channels are characterized by narrow meandering geomorphologies $(25-100 \mathrm{~m}$ wide) fed by low sinuosity dendritic tributaries (Fig. 18 \& 19B). On vertical seismic sections, 
the channels appear as high amplitude incisions overlain by low amplitude reflections (Fig. 19A). This corresponds to the seismic facies F2a, however with more isolated incisions than for the tide-dominated channels (Fig. 15). The main sinuous channels are incised deeper than their tributaries and are also characterized by higher seismic amplitudes (Fig. 19A \& 19B). Geomorphologies such as oxbows, cut-off meanders and point bar deposits (interpreted from higher seismic amplitudes on the inside of channel bends) are observed (Fig. 18 \& 19B). The channels generally drain the ISB from its shallower edges (from the south-west and northwest), merge towards the ISB centre (in the easternmost art of the 3D seismic data) and head to the north (Fig. 9A, $16 \& 17$ ), indicating a general south-to-north flow direction consistent with the present-day bathymetry (Fig. 1A). Channel paths appear to be controlled by the location of the carbonate reefs and the channels bend around" the build-ups at several locations. The abundance of fluvial geomorphologies associated with those channels (analogous with those of the Leichhardt River catchment in the Gulf of Carpentaria; Fig. 19B \& 9C) suggests that they represent fluvial-dominated, incised river systems (Ethridge \& Schumm, 2007; Reijenstein et al., 2011). However in some cases planform geometries are not sufficient to differentiate between fluvial and tidal dominance (Fig. 16).

\section{STRUCTURAL TRENDS}

The Malita intra-shelf basin is bounded by large SW-NE trending normal faults along its edges, dominantly dipping toward the ISB centre (Bourget et al., 2012). Those faults lie outside of the 3D seismic data used in this study. Bourget et al. (2012) showed that these faults have maximum offsets in Miocene and Pliocene strata, with then decreasing offsets towards the surface. In the survey area, seismic attribute maps of D1 (Fig. 8 \& 20B) reveal a complex architecture dominated by $0.5-3 \mathrm{~km}$ wide channelized features following an overall 
SSW-NNE trend (Fig. 7), in addition to a series of 1-8 km-long, SW-NE trending linear features (Fig. 20B). . On cross-section, these correspond to areas where the D1unconformity is vertically offset by faults (Fig. 20C). These faults form conjugate arrays of normal faults dipping towards the ISB centre and mainly offsetting the Miocene and Early Pliocene strata (Fig. 20C). These faults are associated with limited offset of reflections in Unit A (Fig. 20C) and they are not observed along D2 (Fig. 20A). To the northwest, a larger (20 km-long) SWNE oriented and SE dipping fault is observed on both D1 and D2 attribute maps (Fig. 9A), but it is absent from the modern seabed (Fig. 9B). Overall, both fault throw analysis on cross sections (Fig. 20C) and attribute maps of D2 and the seabed (Fig. 9,\& 20A) suggest that faulting in the Malita ISB was minimal from D1 onwards. Fault activity is thus not considered to be an important factor controlling the stratigraphic evolution of the Malita ISB during the Late Pliocene and Quaternary.

In contrast, the reactivation of the Malita ISB during the Neogene (Harrowfield and Keep, 2003) could have played a role on the overall distribution of the carbonate platforms at the onset of the Late Pliocene. Flexural deformation during the Miocene and Pliocene has amplified the differential topography of the Malita intra-shelf basin by uplifting the edges of the ISB and increasing subsidence rates in its centre (Harrowfield and Keep, 2003; Bourget et al., 2012). Above D1 larger carbonate platforms developed along the shallow-water edges of the intra-shelf basin, while smaller and more isolated platforms formed in the deeper-water ISB centre (Fig.6 \& 9). It is here hypothesized that this spatially heterogeneous distribution of carbonate platforms was controlled by the low gradient basement topography shaped by the Mio-Pliocene flexural reactivation of the Malita graben.

\section{SEA-LEVEL, SUBSIDENCE AND ACCOMMODATION}



in this study is obtained from the data of Miller et al. (2005). This sea level record can be combined with paleo-bathymetric reconstructions from 3D seismic data and provide an estimation of subsidence and accommodation in the deepest part of the study area (Fig. 21). 3D seismic attribute analysis of the seismic unconformities D1 to D3 show that these surfaces were associated with widespread tidal and/or fluvial incision (Fig. 7A, 8A, 9, 16, 17, 18 \& 19). Therefore the paleo-bathymetry of these surfaces can be approximated at $\sim 0 \mathrm{~m}$ (Fig. 21A).Using the paleo-sea level record, the estimated paleo-bathymetry of the surfaces and the compacted sediment thickness measured on seismic data, it is thus possible to estimate the burial rates of the surfaces D1, D2 and D3 and deduce the evolution of subsidence rates in the Malita ISB during the late Pliocene and Quaternary (Fig. 21A). Sediment thicknesses were not corrected from compaction and were calculated using a mean velocity of $\mathrm{V}_{\mathrm{p}}=1800 \mathrm{~m} \cdot \mathrm{s}^{-1}$ from seismic data at the deepest location of the ISB centre, at a modern water depth of-135 m (Fig. 21B). Subsidence rates (deflection of the surface D1) were calculated between the age boundaries of the seismic unconformities (Fig. 21A). These estimates have a minimum error of $+/-20 \%$ corresponding to the error range of the sea level data (Miller et al. 2005), with additional error produced by sediment compaction and seismic time/depth conversion. The age of D1 is constrained by the biostratigraphic data of Darwinia-1A (Fig. 11) which suggest that it formed as a response to a major sea level lowstand followed by sea level rise (that reestablished carbonate production) at the end of the Early Pliocene (ca. 3.32 Ma BP; Miller et al., 2005; Fig. 21A).This event would thus correspond to the mid-Pliocene warm period which was associated with global sea level rising 10 to $40 \mathrm{~m}$ above present (Raymo et al., 2011).The age of D2 is more uncertain. Seismic data shows that D2 corresponds to a major emersion event associated with widespread fluvial incision (Fig. 9A \& 18). It forms a major intraQuaternary seismic unconformity which could correlate with the shelf-margin unconformity 
U5" of Bourget et al. (2014). The later marks the termination of carbonate growth and the progradation of mixed clastic-carbonate shelf-edge delta sequences off the mouth of the Malita Valley (Fig. 1A). By correlating the number of shelf-edge sequences with the paleo sea-level record its age was assigned at ca. 0.63 Ma BP (Bourget et al., 2014). This age corresponds to (1) a major sea level lowstand of the Quaternary, reaching -124 m, and; (2) a major climate reorganisation, marked by the transition to 100 kyr-duration glacial cycles associated with higher-amplitude and longer-duration sea-level falls, major lowstands (-90 to - $130 \mathrm{~m}$ below present), and rapid, high amplitude (deglacial) sea-level rises (Fig. 21A, Miller et al., 2005).Thus, we tentatively assign this age to the seismic unconformity D2 which marks both a major platform exposure event and the onset of the progressive demise and burial of the carbonate platforms in the centre of the intra-shelf basin (Fig. 9A). The seismic unconformity D3 is also associated with the development of incised fluvial channels (Fig. 17) and constitutes the youngest evidence of platform exposure in our seismic dataset. Thus, we interpret D3 as the result of the following major lowstand dated ca. 0.44 Ma BP (Miller et al., 2005; Fig. 21A). Sediment core data indicates that Late Quaternary sedimentation rates in the centre of the Malita ISB are in the range of 10-15 cm.ka ${ }^{-1}$ (Yokoyama et al., 2001b). Comparable values $\left(\sim 10 \mathrm{~cm} \cdot \mathrm{ka}^{-1}\right)$ are obtained from the analysis of sediment thickness from seismic data between D2 (ca. $0.63 \mathrm{Ma} \mathrm{BP}$ ) and the modern sea floor ( $65 \mathrm{~m}$ in the ISB center) and D3 (ca. $0.44 \mathrm{Ma}$ BP) and the modern sea floor ( $45 \mathrm{~m}$; Fig. 21). Thus, the proposed ages for D2 and D3 are consistent with the Late Quaternary sedimentation rates measured in this part of the ISB. The resulting subsidence reconstruction highlights two main periods: (1) an initial phase of low to moderate subsidence (55 m/Myr) during Late Pliocene and Early-middle Quaternary (ca.3.32 Ma to ca 0.63 Ma BP); (2) an increase in subsidence during the Late Quaternary (0.63 Ma BP to present) with values of $95 \mathrm{~m} \backslash \mathrm{Myr}$ (between the ages of D2 and D3) and $135 \mathrm{~m} \backslash \mathrm{Myr}$ (between the age of D3 to the present-day). These results 
indicate that the carbonate platforms of the centre of the Malita ISB initially aggraded in a moderately subsiding intra-shelf basin (Unit A), while their progressive demise and burial occurred in a phase of renewed, high subsidence (Fig. 21A).

Combining the subsidence rates with the high resolution sea level data (Fig. 21A) allows estimating the changes in accommodation which occurred in the centre of the Malita ISB during the Plio-Quaternary. Results show that the Late Pliocene and the Early-middle Quaternary (Unit A) were associated with moderately increasing accommodation in the ISB center (30mlMyr on average; Fig. 21C). In contrast, high rates of accommodation creation occurred during the Late Quaternary (from 0.63 Ma BP onward), with a mean of $130 \mathrm{~m} / \mathrm{Myr}$.

\section{DISCUSSION}

\section{SEQUENCE STRATIGRAPHIC EVOLUTION OF THE} MALITA INTRA-SHELF BASIN

The combination of $2 \mathrm{D}$ and $3 \mathrm{D}$ seismic stratigraphic interpretation integrated with well data and accommodation data allow building a sequence stratigraphic framework for the Malita ISB during the Plio-Quaternary (Fig. 22). Seismic stratigraphy and geomorphology show that the Plio-Quaternary strata of the Malita ISB comprises two main unconformities (D1 \& D2; Fig. 4, $6 \&$ 22). These unconformities are associated with widespread fluvial and $\backslash$ or tidal geomorphologies (Fig. 14, 16\& 22) indicative of sea-level lowstands (Fig 21A), and they are interpreted as subaerial unconformities (sensu Catuneanu et al., 2009). The unconformities D1 and D2 are locally overlain by aggrading carbonate platforms and build-ups (Fig 4, 5, 6) 
which commonly form in periods of rising and/or high sea levels. Thus, we interpret these seismic unconformities as the stack of a subaerial unconformity and a transgressive surface, and D1 and D2 are interpreted as $3^{\text {rd }}$-order sequence boundaries (Fig. 23).Contrarily to D1 and D2, D3 does not mark a significant change in seismic facies and carbonate growth trend (Fig. 4, $5 \& 6)$ and is thus interpreted as an unconformity of higher stratigraphic order $\left(4^{\text {th }}-\right.$ order sequence boundary). The seismic units A and B form two distinct phases of carbonate growth in the Malita ISB (Fig. 6 \& 22). Unit A is associated with the aggradation of wide carbonate platforms along both the ISB edge and its centre, while Unit B shows limited carbonate growth in the ISB center, which becomes restricted to the aggradation of small isolated build-ups (Fig 7, $8 \&$ 22).Carbonate aggradation is typically associated with periods of relative sea-level rise (e.g. Kendall and Schlager 1981, Emery and Myers, 1996). The observation of aggrading carbonate geometries in Unit A and B is consistent with the calculated increases of accommodation in the centre of the Malita ISB during the Plio-

Quaternary (Fig. 21C). Thus Unit A (ca. 3.3 to $0.63 \mathrm{Ma} \mathrm{BP}$ ) and Unit B(ca. 0.63 Ma BP to present day) represent two $3^{\text {rd }}$-order transgressive sequences (Embry, 2002; Catuneanu et al., 2009) bounded by two sequence boundaries (Fig. $21 \& 22$ ).

\section{Late Pliocene and Early to middle Quaternary: carbonate platform} aggradation in the Malita ISB

The growth of carbonate platforms in Unit A initiated during the transgression that followed the $-60 \mathrm{~m}$ Early Pliocene sea level lowstand (sequence boundary D1; Fig. 11 \& 21), corresponding to the mid-Pliocene warm period (Raymo et al., 2011). In the ISB centre carbonate platform aggradation took place with moderate rates of accommodation creation ( $\sim 30 \mathrm{~m} \backslash$ Myr; Fig. $21 \mathrm{C})$ corresponding to the -start-up" and -eatch-up" phases (Kendall and 
Schlager, 1981;Sarg, 1988; Jacquin et al., 1991; Emery and Myers, 1996). However Unit A is associated with a spatially heterogeneous carbonate growth rate (e.g., the differential carbonate aggradation of Razin et al., 2010) which led to the differentiation of isolated carbonate platforms (where the carbonate production could catch up with the relative sea level rise) separated by interplatform seaways and basins (where carbonate production could not catch up with the rising sea level).

While Unit A forms a $3^{\text {rd }}$-order transgressive sequence marked by the aggradation of carbonate platforms, the widespread evidences of tidal geomorphologies (Fig.7, 14, 15) also suggests that the intra-shelf basin was episodically associated with at least very shallow, intertidal water depth, i.e. $<10 \mathrm{~m}$ (considering the modern spring tidal range).Within Unit $\mathrm{A}$, the top of carbonate platforms can locally culminate at $30-90 \mathrm{~m}$ above the adjacent paleo seabed where tidal depositional geometries develop (Fig. 4, 7B \& 8A). Although this difference of elevation is likely amplified by the lateral variations of seismic velocities in carbonate settings (pull-ups), it suggests the occurrence of higher-frequency sea-level fluctuations during an overall $3^{\text {rd }}$-order transgressive sequence. The growth of carbonate build-ups would occur during the high-frequency $\left(4^{\text {th }}\right.$-order) sea-level rises and highstands (Kendal and Schlager, 1981; Schlager, 2005), while lower sea-levels (4 ${ }^{\text {th }}$-order lowstands) would allow the formation of tidal flat channels in the low-lying areas of the ISB (Fig. 19). Likewise, the inter-platforms seaways (Fig. $12 \& 13$ ) were associated with corridors of increased current velocities located in between the flooded carbonate platforms during the $4^{\text {th }}$ order transgressions and highstands. These high velocities current prevented carbonate deposition and platform progradation in these seaways resulting in long-live features (e.g. Bachtel et al., 2004). During $4^{\text {th }}$-order lowstands, fluvial and/or tidal incisions were thus confined in these topographic lows in between surrounding carbonate platforms (Fig. 18A).These observations are consistent with the high-frequency sea-level fluctuations 
recorded between 3.5 and 0.63 Ma BP (Miller et al., 2005; Fig. 21A). This is also consistent with previous observations in the nearby Gulf of Papua, where Late-Pliocene-Pleistocene successions of mixed siliciclastic-carbonate sequences were interpreted to be the result of high-frequency sea-level fluctuations through the last million years (Tcherepanov et al., 2010; Droxler and Jorry, 2013).

\section{Late Quaternary: demise of the carbonate platforms in the centre of the ISB}

The Late Quaternary is associated with a strong reduction of carbonate production and by the progressive infill of the centre of the Malita ISB (Fig. 6, $9 \& 22$ ). Once the platforms have been re-flooded (after the D2 major exposure event), they underwent an important backstepping episode and carbonate production occurred only on top of the highest topographies of the underlying platforms (Fig. $8 \& 22$ ). Carbonate growth becomes therefore restricted to small isolated build-ups (Fig. 17 \&22). The apparent reduction of carbonate production in the centre of the Malita ISB was also accompanied by the partial drowning and progressive burial of the carbonate platforms from Unit A (Fig. 6, 9B \& 22). Drowning of carbonate platforms and subsequent burial are often interpreted as the result of a rapid increase of accommodation, overtaking the rates of platform growth and leading to a giveup" phase" (e.g.,Kendall and Schlager, 1981; Sarg, 1988; Zampetti et al., 2004; Schlager, 2005). This is consistent with the Late Quaternary estimations of subsidence rates (95 to $135 \mathrm{~m} \backslash \mathrm{Myr})$ which led to an increase in rate of accommodation creation during the deposition of Unit B (Fig. 21). Above D3, the absence of channelized morphologies laterally to the carbonate build-ups in Unit B suggests that the centre of the ISB was deep enough to prevent complete platform exposure during he repeated lowstands of the Late Quaternary (Fig. 21A). This is consistent with the observations of Yokoyama et al. (2001b) and Bourget et al. (2013) 
593

594

595

596

597

598

599

600

601

602

603

604

605

606

607

608

609

610

611

612

613

614

615

616

617

and supports the hypothesis of increased subsidence during the late Quaternary at this location.

However, demise and burial of carbonate platforms can also be caused by a reduction of carbonate production due to increased nutrient levels including terrigenous input (-elastic pollution"; Kendall and Schlager, 1981; Hallock and Schlager, 1986). The Late Quaternary coincides with increased continental denudation rates in NE Australia (Nott and Roberts, 1996), that would have led to enhanced terrigenous supply in the intra-shelf basin and to the shelf-margin (Bourget et al., 2013, 2014). Siliciclastic sediment input during the sea levels lowstands of the Late Quaternary is supported by both sedimentological and geomorphological evidence (van Andel and Veevers, 1967; Lees et al., 1992; Yokoyama et al., 2000, 2001a, b; Anderson et al., 2011; Nicholas et al., 2014). Late Quaternary and surface sediment samples in the ISB centre are composed by mixed (terrigenous and carbonate) mud and silt deposits (van Andel and Veevers, 1967; Yokoyama et al., 2000, 2001a). Shelf bathymetry and very high-resolution seismic data revealed the presence of Late Quaternary fluvial valleys incising the Bonaparte shelf more than $120 \mathrm{~km}$ from the modern coastline (Nicholas et al., 2014). Clastic input during the repeated sea level lowstands of the Late Quaternary resulted in the progradation of a large shelf edge delta at the margin of the Bonaparte Basin from 0.63 Ma BP to the present day (Bourget et al., 2014). Therefore, it is possible that the demise of carbonate platforms and the infill of the ISB centre during the Late Quaternary resulted from a combination of (1) strong and rapid increase of accommodation due to renewed subsidence, and (2) deterioration of carbonate factory health via high terrigenous input.

D3 corresponds to the youngest period of platform exposure in the Malita ISB (0.44 Ma BP; Fig. 21A). With only two discrete episodes of platform exposure and fluvial sedimentation observed in the seismic data in Unit B (D2 and D3), any input of terrigenous 
particles in the intra-shelf basin during the Late Quaternary would have occurred while the platform is underwater. Late Quaternary sediments recovered in the center of the Malita intrashelf basin show that lowstand sediments consist of marginal marine to brackish silts and muds (Yokoyama et al., 2000; Yokoyama et al., 2001a). In lowstands the intra-shelf basin formed an internal sea connected to the open ocean through the Malita Valley (Yokoyama et al., 2001b; Bourget et al., 2013; Fig. 1). As a consequence terrigenous input in the Malita ISB in Unit B was predominantly indirect, consisting of reworked fine-grained sediments originated from the fluvial systems incising the inner shelf during the repeated high-frequency $\left(4^{\text {th }}\right.$-order) sea-level fall and lowstands, within an overall $\left(3^{\text {rd }}\right.$-order $)$ transgression.

\section{Late Quaternary: differential subsidence and spatial heterogeneity in}

\section{carbonate growth in the Malita ISB}

The Late Quaternary transgression and increase in terrigenous input did not completely shut down the carbonate sedimentation along the Bonaparte shelf. Seismic data suggests that the western edge of the Malita ISB was less - or not - affected by platform drowning and burial during the late Quaternary (Fig $6 \&$ 9B). At present day the shallow carbonate platforms bounding the ISB centre are located at -30 to $-60 \mathrm{~m}$ (Fig. 1). Modern sediment samples show that these shallow platforms are associated with a healthy and active coralgal production (Anderson et al., 2011). In contrast, the top of the isolated carbonate build-ups located in the ISB centre (Fig. 9B) are now culminating at $90-120 \mathrm{~m}$ water depth (Fig. 6), i.e. below the optimal water depths allowing carbonate production (Schlager, 2005). Pre-drill environmental site surveys along those build-ups confirmed that they are drowned reefs with mostly inactive carbonate production (George \& Cauquil, 2010). Therefore, carbonate production remained active along the shallower-water edges of the intra-shelf basin 
643

during the Late Quaternary and the demise the carbonate platforms mostly occurred in the centre of the basin (Fig. 6). This spatial heterogeneity in carbonate production can be 645 explained by differential subsidence. Neogene reactivation of the Malita Basin occurred 646 through long-wave length flexural reactivation of the rift-inherited basement topography (Harrowfield \& Keep, 2005; Bourget et al., 2012), which resulted in higher subsidence rates 648 in the basin centre and lesser subsidence rates along its edges. It is possible that similar 649 deformation mechanisms accompanied the Late Quaternary phase of renewed subsidence in 650 the intra-shelf basin, and lead to differential tectonic subsidence which directly impacted the evolution of platforms and build-ups geometries (Fig. 23).It is here hypothesized that the Late
Quaternary carbonate sedimentation of the Malita ISB is slightly diachronous, as the highfrequency $\left(4^{\text {th }}\right.$-order $)$ sea-level changes did not similarly affect the carbonate factory of the shallow-water ISB edges and its deeper, more subsiding, centre (Fig. 23):

- during the sea level lowstands (glacial; Fig. 21) the shallow platforms of the Malita ISB were exposed but the carbonate build-ups of the basin centre remained underwater (Fig. 23). However fine-grained terrigenous sediments were then brought to the basin (Yokoyama et al., 2001a, 2001b; Bourget et al., 2013, 2014) and the carbonate factory was likely to be limited or shut down(Fig. 23);

- during the high-amplitude sea level rise phases (deglacial; Fig. 21), carbonate growth could resume along both the shallow-water platforms and the build-ups of the basin centre. However the later were located in deeper water, in a rapidly subsiding basin, which prevented them from catching-up with the abruptly rising sea levels (Fig.23). As a result, the build-ups of the ICB centre drowned during the highstand (interglacial) phases (Fig. $21 \& 23$ ). This contrasts with the shallow carbonate platforms of the ISB edges which could catch-up and keep-up with the relative sea- 
level rise and remained actively growing in highstands (e.g., the present-day configuration; Anderson et al., 2011).

Thus, the spatial heterogeneity in carbonate distribution observed in the Late Quaternary strata of the Malita ISB likely results from the impact of differential subsidence (as well as clastic pollution) on carbonate geometries and their response to high-amplitude, high-frequency eustatic variations.

\section{COMPARISON WITH ANCIENT INTRA-SHELF BASINS}

The Plio-Quaternary architecture and stratigraphic evolution of the Malita ISB share both similarities and differences with Palaeozoic and Mesozoic age carbonate rich intra-shelf basins (Markello and Read, 1982; Pratt and James, 1986; Droste 1990; Burchette and Wright, 1992; Van Buchem et al., 2002; Droste and Steenwikel, 2004; Razin et al. 2010). The best documented carbonate-rich ISBs are the Early to middle Cretaceous ISBS of the Middle East, which formed 50-100 $\mathrm{m}$ deep basins extending hundreds of kilometers across extensive shallow water platforms (Murris 1980; Van Buchem et al, 2002). The age of the Malita ISB (from its initiation ca. 3.5 Ma BP to the present day) is comparable with the typical duration of a complete cycle of initiation and filling of the Arabian ISBs (ca. 2.5 - 7 Ma; Droste, 2010; van Buchem et al., 2011). In both ancient systems and the Malita ISB, the $3^{\text {rd }}$-order stratigraphic architecture is mainly driven by the fluctuations in accommodation. The initiation of ancient intra-shelf basins and their first stages of evolution were associated with $3^{\text {rd }}$-order transgressive events marked by differential sedimentation rates (Van Buchem et al., 2010; Droste, 2010), where carbonate growth initiated along low gradient basins associated with a subtle topography (Razin et al., 2010). In the Malita ISB, Late Pliocene transgression 
690

691

692

693

694

695

696

697

698

699

700

701

702

703

704

705

706

707

708

709

710

711

712

713

714

occurred over a low gradient basement topography shaped by the Mio-Pliocene flexural reactivation of the Malita Graben (Harrowfield et al., 2003; Bourget et al., 2012). In the ISB centre, differential carbonate aggradation in Unit A resulted in depositional geometries comparable with those observed in the Arabian ISBs (Van Buchem et al, 2002; Droste and Steenwikel, 2004; Droste, 2010; Razin et al., 2010), e.g. km-scale individual platforms separated by seaways and deeper water inter-platform areas. The carbonate platforms of the Arabian ISBs rose 40-70 m above the surrounding inter-platform lows (Razin et al., 2010), comparable with the values observed in the Malita ISB in Unit A. In the ISB center, data available suggest that the carbonate platforms preferentially grew on subtle topographic highs probably associated with erosional highs and/or positive topography induced by underlying carbonate platforms of Miocene age (Fig. 10). In fossil ISBs (Van Buchem, 2002; Droste, 2010), it was also proposed that the heterogeneous distribution of carbonates resulted from subtle variations in basin topography induced by sand dunes, faulting, salt doming or flexural isostacy (Aigner et al., 1989; Droste, 2004, Jorry and Bievre, 2011).Razin et al. (2010) estimated the rate of accommodation under which differential carbonate aggradation occurred in the Cenomanian-Turonian ISBs of Iran in the range of 30-50 m/Myr, e.g., comparable to the estimated accommodation of Unit A in this study. Under those conditions, and despite the differences in carbonate biota (e.g., dominance of rudists in the Cretaceous; Droste et al., 2010), the carbonate factories of both systems were locally able to keep up with the relative sea level rise. Thus, in both the Cretaceous Arabian and Malita examples the initial architecture of the ISBs resulted from differential carbonate aggradation in conditions of relative sea level rise and low to moderate subsidence (Razin et al., 2010).

In the Cretaceous ISBs of Arabia this initial transgressive period was commonly followed by regression and progradation of the ISB platforms, which in cases coalesced into larger platforms and filled up the inter-platform areas (Droste et al., 2010; Razin et al., 2010). 
Decreasing accommodation was commonly accompanied with progressive emersion of the carbonate platforms, channel incision and clastic infill of the remaining seaways between the platforms. This upper regressive sequence terminates the $3^{\text {rd }}$-order depositional cycles of the Arabian ISBs (Droste et al., 2010). In contrast, platform exposure in the Malita ISB (D2 \& D3) did not result from a long-term sea level fall and regressive conditions, but rather from two episodic, high-amplitude glacial lowstands at 0.63 and 0.44 Ma BP (Fig. 21A). Widespread progradation of the ISB platforms did not occur because tectonically-induced, differential subsidence induced a second $3^{\text {rd }}$-order transgressive cycle (Fig. 22). While carbonate aggradation continued along the edges of the intra-shelf basin, platforms within the rapidly subsiding ISB center could not keep up with the repeated, $4^{\text {th }}$-ordersea level rises and were progressively smothered by the clastic input during the $4^{\text {th }}$-order lowstands (Fig. $22 \&$ 23). Thus, the Cretaceous ISBs of Arabia were mainly controlled by eustasy (Razin et al., 2010), whilst the stratigraphic architecture of the Malita ISB is strongly controlled by differential subsidence and the occurrence of high-frequency, high-amplitude eustatic variations superimposed to the $3^{\text {rd }}$-order changes in accommodation. These constitute major differences between the stratigraphic evolution of the Arabian and Malita ISBs that are, moreover, concomitantly associated with different climatic conditions (i.e. greenhouse for the Cretaceous ISBs of Arabia and icehouse for the Plio-Quaternary Malita ISB).

Tidal and fluvial incisions are widespread in the Arabian ISBs and they can have a major impact on reservoir architecture and heterogeneity depending of their size, their stratigraphic occurrence and the properties of their infill (Grelaud et al., 2005; 2010). Wide (1-2 km) and long (>100 km) incisions developed along sequence boundaries at the top of the $3^{\text {rd }}$-order regressive sequences in the ISBs or Arabia (Grelaud et al., 2010). Channels formed along the top of the exposed platforms and drained into the inter-platform areas and seaways in between the platforms (Droste et al., 2010). Comparable geomorphologies are observed in 
the Malita ISB and D2 forms a $3^{\text {rd }}$-order sequence boundary separating the two transgressive cycles (Fig. 22). While the lowstand incisions developing at the top of the Arabian ISB platforms are filled with carbonate sediments during subsequent transgressions (Grelaud et al., 2010), the fluvial channels mapped on D2 and D3 are associated with point-bar deposits in the inter-platform areas (Fig. 18 \& 19) suggesting the occurrence of sandy fluvial deposits embedded within low-amplitude (presumably mud-rich) deposits above and below them (Fig. $4 \& 5)$. Tidal and fluvial channels are also widely developed in the seaways and interplatform lows separating the carbonate platforms. Such features could potentially form isolated clastic reservoirs associated with stratigraphic traps within an overall ISB carbonate setting.

\section{CONCLUSION}

This study shows that the Bonaparte Basin is an outstanding region for studying the depositional geometries and the controls on stratigraphic architecture of intra-shelf basin carbonates in a low-latitude, very wide shelf setting. Intra-shelf basin carbonate sedimentation initiated following a late Pliocene transgression over a low gradient basement topography shaped by the Mio-Pliocene flexural reactivation of the Malita graben. This basement topography (and its later reactivation during the Late Quaternary) had a major influence on the spatial distribution of carbonates in the basin. Indeed, wider and more densely distributed platforms initially developed along the edges of the Malita ISB while smaller and more isolated platforms formed in its deeper centre. This configuration persisted to the present day.

In the ISB centre, the first transgressive cycle (Late Pliocene to middle Quaternary) was accompanied by differential carbonate aggradation which resulted in the formation of 3-10 $\mathrm{km}$-wide isolated platforms, aggrading and rising 30-90 $\mathrm{m}$ above the interplatform areas. This 
basal transgressive cycle terminated with a short-duration, high-amplitude eustatic fall event which caused widespread platform exposure and fluvial incision. Following this exposure event a major increase in subsidence rates initiated a new transgressive cycle marked by the progressive demise and burial of the platforms in the ISB center. High amplitude $(>100 \mathrm{~m})$, high frequency (ca. $100 \mathrm{kyr}$ ) eustatic variations superimposed to this longer-term $\left(3^{\text {rd }}\right)$ transgression trend. In the rapidly subsiding ISB center the carbonate platforms were repeatedly drowned during the abrupt postglacial sea level rises, and progressively smothered by clastic sediments brought into the basin during the repeated high-amplitude lowstands. In contrast, carbonate platform aggradation continued along the shallow-water edges of the Malita ISB throughout the Late Quaternary. This suggests that differential subsidence took place, probably as a result of a renewed flexural reactivation of the Malita Graben. This mechanism is at the origin of the spatially heterogeneous distribution of the intra-shelf basin carbonates.

The Plio-Quaternary Malita ISB constitutes the first real modern analogue for ancient intra-shelf basins that formed along wide epeiric shelves and commonly host important hydrocarbon accumulations. Comparison with the Cretaceous ISBs of the Middle East suggests that the main mechanism controlling the global architecture of ISB carbonates is differential carbonate aggradation over an irregular shelf topography during an initial transgressive phase. However, the occurrence of differential subsidence, its impact on the rates of accommodation creation and the superimposition of high-frequency, high-amplitude eustatic cycles on these $3^{\text {rd }}$-order trends appear as major controls on the stratigraphic evolution of the Malita ISB carbonates. This constitutes a major difference with ancient intrashelf basins successions which are thought to be dominantly controlled by eustasy. 
Aigner, T., Doyle, M., Lawrence, D., Epting, M., Van Vliet, A., 1989, Quantitative modelling

Special Publications., v. 44, p. 27-37.

Al-Emadi, Jorry, S.J., Chautru, J.M., Caline, B., Blum, M.S., Jedaan, N., Fryer, V., Leandri, P., Fraisse, C., 2009, 3D modeling of the Arab Formation (Maydan Mahzam Field, Offshore Qatar): an integrated approach. International Petroleum Techonology Conference, 7-9 December 2009, Doha, Qatar, IPTC 13461-PP, 17p.

Allison, P.A., Wells, M.R., 2006, Circulation in large ancient epicontinental seas: What was different and why?: Palaios, v. 21, p. 513-515.

Alsharhan, A.S. and A.E.M., Nairn, 1993. Carbonate platform models of Arabian Cretaceous reservoirs. In J.A.T. Simo, R.W. Scott and J.-P. Masse (Eds.), Cretaceous carbonate platforms. AAPGMemoir 56, p. 173-184

Anderson, T. J., Nichol, S., Radke, L., Heap, A. P., Battershil,C., Hughes,M., Siwabessy,P. J., Barrie, V., Alvarez DeGlasby, B., Tran, M., Daniell, J., Shipboard party, 2011, Seabed Environments of the Eastern Joseph Bonaparte Gulf, Northern Australia, GA03235/Sol5117 Post-survey report Geoscience Australia.

Audley-Charles M.G., Carter D.J., 1972,Palaeogeographical significance of some aspects of Palaeogene and Early Neogene stratigraphy and tectonics of the Timor Sea region: Palaeogeography, Palaeoclimatology, Palaeoecology, v. 11, p. 247-264.

Audley-Charles, M.G., 1986, Timor-Tanimbar Trough: The foreland basin to the evolving Banda orogen. In: Allen P. A., Homewood P. eds. Foreland basins, p. 91-02. International Association of Sedimentologists Special Publication, v. 8.

Bachtel, S.L., Kissling, R.D.,Martono, D., Rahardjanto, S.P., Dunn, P.A., MacDonald, B.A., 2004, Seismic Stratigraphic Evolution of the Miocene-Pliocene Segitiga Platform, East Natuna Sea, Indonesia: The Origin, Growth, and Demise of an Isolated Carbonate Platform,In: G. Eberli, J.L. Massaferro and J.F.R. Sarg (Eds.), Seismic Imaging of Carbonate Reservoirs and Systems. AAPG Memoir, v. 81, p. 309-328.

Baillie, P.W., Mc Powell, C., Li Z.X., Ryall, A.M., 1994, The tectonic framework of Western Australia's Neoproterozoic to Recent sedimentary basins. In: Purcell P. G. P. \& Purcell R. R.eds. The sedimentary basins of Western Australia, p. 45-62. Proceedings of the Petroleum Exploration Society of Australia Symposium, Perth.

Berkeley, A., Rankey, E.C., 2012, Progradational Holocene carbonate tidal flats of Crooked Island, south-east Bahamas: An alternative to the humid channelled belt model: Sedimentology, v. 59, p. 1902-1925

Bourget, J., Ainsworth, R.B., Backe, G., Keep, M., 2012, Tectonic Evolution of the northern Bonaparte Basin: Impact on Continental Shelf Architecture and Sediment Distribution during 
the Pleistocene: Australian Journal of Earth Sciences, v. Special Issue "Dynamics and Evolution of the Indo-Australian Plate". p. 877-897

Bourget, J., Ainsworth R.B., Nanson, R., 2013, Origin of mixed carbonate and siliciclastic sequence at the margin of a "giant" platform during the Quaternary (Bonaparte Basin, NW Australia). In Verwer, K., Playton, T.E., Harris, P.M., Deposits, Architecture, and controls of Carbonate Margin, Slope, and Basinal Settings, Special Publication 105: SEPM (Society for Sedimentary Geology), Tulsa, OK. doi: 10.2110/sepmsp. 105.17.

Bourget, J., Ainsworth R.B., Thompson, S., 2014, Seismic stratigraphy and geomorphology of a tide dominated shelf-edge delta (NW Australia): process-based classification from 3D sesimic attributes and implication for the prediction of deep-water sands: Marine and Petroleum Geology, v. 57, p. 359-384

Burchette, T.P., and Wright, V.P., 1992, Carbonate Ramp Depositional Systems: Sedimentary Geology, v. 79, p. 3-57.

Burgess, P.M., P. Winefield, M. Minzoni, C., Elders, 2013, Methods for identification of isolated carbonate build-ups from seismic reflection data: AAPG Bulletin, v. 97, p. 10711098.

Catuneanu, O., Abreu, V., Bhattacharya, J. P., Blum, M. D., Dalrymple, R. W., Eriksson, P. G., Fielding, Christopher R., Fisher, W. L., Galloway, W. E., Gibling, M. R., Giles, K. A., Holbrook, J. M.; Jordan, R., Kendall, C. G. St.C., Macurda, B., Martinsen, O. J., Miall, A. D., Neal, J. E., Nummedal, D., Pomar, L., Posamentier, H. W., Pratt, B. R., Sarg, J. F., Shanley, K. W., Steel, R. J., Strasser, A., Tucker, M. E.,Winker, C., 2009, Towards the Standardization of Sequence Stratigraphy: Papers in the Earth and Atmospheric Sciences. Paper 238.

Davies, R.J., Posamentier, H.W., Wood, L.J., Cartwright, J.A., 2007, Seismic Geomorphology: Applications to Hydrocarbon Exploration and Production: Geological Society, London, Special Publications, v. 277, p 1-14.

deRuig, M.J., Trupp, M., Bishop, D.J., Kuek, D.,Castillo, D.A., 2000, Fault architecture and the mechanics of fault reactivation in the Nancar Trough/Laminaria area of the Timor Sea, northern Australia. : APPEA Journal (Australian Petroleum Production and Exploration Association), v. 40, p. 174-193.

Droste, H., 1990, Depositional cycles and source rock development in an epeiric intraplatform basin: the Hanifa Formation of the Arabian Peninsula: Sedimentary Geology, v. 69, p. 281-296.

Droste, H.J., VanSteenwinkel, M., 2004, Stratal geometries and patterns of platform carbonates: the Cretaceous of Oman. In, G. Eberli, J.L. Massaferro and J.F.R. Sarg (Eds.), Seismic Imaging of Carbonate Reservoirs and Systems. AAPG, Memoir 81, p. 185-206.

Droste, H., 2010, High-resolution seismic stratigraphy of the Shu'aiba and Natih formations in the Sultanate of Oman: implications for Cretaceous epeiric carbonate platform systems: Geological Society, London, Special Publications, v. 329, p. 145-162.

Droxler, A.W., Jorry, S.J., 2013,Deglacial origin of barrier reefs along low-latitude mixed siliciclastic and carbonate continental shelf edges: Annual Review of Marine Science, v. 5, p. 165-190. 
Eberli, G.P., and Ginsburg, R.N., 1987,Segmentation and coalescence of Cenozoic carbonate platforms, northwestern Great Bahama Bank: Geology, v. 15, p. 75-79.

Elmore, R.D., Muxworthy, A.R., Aldana, M., 2012, Remagnetization and chemical alteration of sedimentary rocks: Geological Society, London, Special Publications, 2012, v. 371, p.1-21.

Emery, D., Myers, K.J., 1996, Sequence Stratigraphy, London, BP exploration, 297p.

Ethridge, F.R., Schumm, S.A., 2007, Fluvial seismic geomorphology: a view from the surface. In: Davies, R.J., Posamentier, H.W., Wood, L.J., Cartwright, J.A. (Eds.), Seismic Geomorphology: Applications to Hydrocarbon Exploration and Production, Geological Society Publication, v. 277, p. 205-222

Fagherazzi, S., Furbish, D.J., 2001, On t.he shape and widening of salt marsh creeks, J. Geophys. Res., v.106, p. 991-1003

Frankowicz, E., McClay, K.R., 2010, Extensional fault segmentation and linkages, Bonaparte Basin, outer North West Shelf, Australia: AAPG Bulletin, v. 94, p. 977-1010.

Embry, A.F., 2002. Transgressive-regressive (TR) sequence stratigraphy, Gulf Coast SEPM Conference Proceedings, Houston. SEPM, p. 151-172.

Emery, D., Myers, K.J., 1996, Sequence Stratigraphy, London, BP exploration, 297p.

Frankowicz, E., McClay, K.R., 2010, Extensional fault segmentation and linkages, Bonaparte Basin, outer North West Shelf, Australia: AAPG Bulletin, v. 94, p. 977-1010.

George, T., Cauquil, E., 2010, A multi-disciplinary site investigation for the assessment of drilling geohazards and environmental impact within the northern Bonaparte Basin. Preview148,p. 41-44.

Grelaud, C., 2010, Enregistrement stratigraphique des phases d'émersion sur les plates-formes carbonatées, Phd, University Michel de Montaigne, Bordeaux, 217p.

Grelaud, C., Razin, Ph., Homewood, P., Schwabs, A. M., 2006, Development of incisions on a periodically emergent carbonate platform (Natih Formation, Late Cretaceous, Oman): Journal of Sedimentary Research, Vol. 76, p. 647-669.

Grelaud, C., Razin, Ph., Homewood, P., 2010, Channelized systems in an inner carbonate platform setting: differentiation between incisions and tidal channels (Natih Formation, Late Cretaceous, Oman). Geological Society, London, Special Publications, Vol. 329, $n^{\circ}$ Mesozoic and Cenozoic Carbonate Systems of the Mediterranean and the Middle East: Stratigraphic and Diagenetic Reference Models, Van Buchem, F. S. P., Gerdes, K. D. \&Esteban, M. (eds), p. 163-186.

Grover, G.J., 1993, Intrashelf basins: A geological model for source-bed and reservoir facies deposition within carbonate shelves, AAPG, v. 77, 9.

Haig, D.W., 2012, Palaeobathymetric gradients across Timor during 5.7-3.3 Ma (latest Miocene-Pliocene) and implications for collision uplift: Palaeogeography, Palaeoclimatology, Palaeoecology, v. 331-332, p. 50-59. 
Haig, D.W., Bandini, A.N., 2013, Middle Jurassic Radiolaria from a siliceous argillite block in a structural melange zone near Viqueque, Timor Leste: paleogeographic implications: Journal of Asian Earth Sciences, v. 75, p. 71-81.

Hall,R., 2002, Cenozoic geological and plate tectonic evolution of SE Asia and the SW Pacific: computer-based reconstructions, models and animations: Journal of Asian Earth Sciences, v. 20, p 353-431.

Hallock, P., Schlager, W., 1986, Nutrient Excess and the Demise of Coral Reefs and Carbonate Platforms, PALAIOS, v. 1, p. 389-398.

Harrowfield, M., Cunneen, J., Keep,M., Crowe,W., 2003, Early stage orogenesis in the Timor Sea region, NWAustralia: Journal of the Geological Society of London, v. 160, p. 991-1001.

Hine, A.C., Locker, S.D., Tedesco, L.P., Mullins, H.T., Hallock, P., Belknap, D.F., Gonzales, J.L., Neumann, A.C., Snyder, S.W., 1992, Megabreccia shedding from modern, low relief carbonate platform, Nicaraguan Rise, GSA Bulletin, v. 104, p. 928-943

Hughes, Z.J., 2012, Tidal Channels on Tidal Flats and Marshes, p. 269-300 in Davis Jr., R.A., Dalrymple, R.W., eds. Principles of Tidal Sedimentology, Springer-Verlag, 621p.

Irwin, M.L., 1965, General theory of epeiric clear water sedimentation: American Association of Petroleum Geologists Bulletin, v. 49, p. 445-459.

Jacquin, T., Arnaud-Vanneau, A., Arnaud, H., Ravenne, C.,Vail, P.R., 1991, Systems tracts and depositional sequences in a carbonate setting: a study of continuous outcrops from platform to basin at the scale of seismic lines: Marine and Petroleum Geology, v. 8, Issue 2, p. 122-139., p. 2010-2026.

Jacquin, T., Arnaud-Vanneau, A., Arnaud, H., Ravenne, C.,Vail, P.R., 1991, Systems tracts and depositional sequences in a carbonate setting: a study of continuous outcrops from platform to basin at the scale of seismic lines:Marine and Petroleum Geology, v. 8, Issue 2, p. 122-139., p. 2010-2026.

Jorry, S.J., Bievre, G., 2011, Integration of sedimentology and ground-penetrating radar for high-resolution imaging of a carbonate platform: Sedimentology, v. 58, p. 1370-1390.

Keep M., Bishop, A., Longley, I.M., 2000, Neogene wrench reactivation of the Barcoo subbasin, northwest Australia: implications for Neogene tectonics of the northern Australian margin: Petroleum Geoscience, v. 6, p. 211-220.

Keep, M.,Haig, D.W., 2010, Deformation and exhumation in Timor: Distinct stages of a young orogeny: Tectonophysics, v. 483, p. 93-111.

Kendall, C.G., Schlager, W., 1981, Carbonates and relative changes in sea level: Marine Geology, v. 44, p. 181-212.

Kreemer, C., Holt, W.E., Goes, S., Govers, R., 2000, Active deformation in eastern Indonesia and the Philippines from GPS and seismicity data: Journal of Geophysical Research v. 105, p. 663-680.

Langhi, L., Ciftici, N.B., Borel, G.D., 2011, Impact of lithospheric flexure on the evolution of shallow faults in the Timor foreland system: Marine Geology, v.730, p. 40-54. 
Leblanc, R.J., 1972, Geometry of Sandstone Reservoir Bodies, AAPG Special Volumes, A075, p.133-189.

Lees, B.G., 1992, Recent terrigenous sedimentation in Joseph Bonaparte Gulf, Northwestern Australia: Marine Geology, v. 103, p. 199-213.

Longley, I.M., Buessenschuett, C., Clydsdale, L., 2002, The North West Shelf of AustraliaA Woodside perspective v. 3, p. 27-88., in Keep, M., and Moss, S., eds., Sedimentary basins of Western Australia: Petroleum Exploration Society of Australia Symposium Proceedings, p. $27-88$.

Markello, J.R., Read, J.R., 1982, Upper Cambrian intrashelf basin, Nolichucky Formation, southwest Virginia Appalachians: AAPG Bulletin, v. 66, no. 7, p. 860-878.

Martini, E., 1971, Standard Tertiary and Quaternary Calcareous Nannoplankton Zonation. Proceedings ofthe II Planktonic Conference, Roma , 1970, A. Farinacci, ed., Ed. Tecnoscienza, p. 739 - 785, Rome.

Miller, K.G., Kominz, M.A., Browning, J.V., Wright, J.D., Mountain, G.S., Katz, M.E., Sugarman, P.J., Cramer, B.S., Christie-Blick, N., \&Pekar, S.F., 2005, The phanerozoic record of global sea-level change: Science, v. 310, p. 1293-1298.

Mitchum, R.M., JR., Vail, P.R., Thompson, S., III 1977, Seismic stratigraphy and global changes of sea level; Part 2, The depositional sequence as a basic unit for stratigraphic analysis, in PaytonC.E., 1977, Seismic stratigraphy; applications to hydrocarbon exploration, American Association of Petroleum Geologists Memoir, v. 26, p. 53-62.

Murris, R.J., 1980, Middle East: stratigraphic evolution and oil habitat: AAPG Bulletin, v. 64, p. 597-618.

Nott, J., Roberts, R.G., 1996, Time and process rates over the past 100 my: A case for dramatically increased landscape denudation rates during the Late Quaternary in northern Australia: Geology, v. 24, p. 883-887.

O'Brien,G.W., 1993, Some ideas on the rifting history of the Timor Sea from the integration of deep crustal seismic and other data: Petroleum Exploration Society of Australia Journal, v. 21, p. 95-113.

O’Brien, G.W., Lisk, M., Duddy, I., Eadington, P.J., Cadman P., Fellows, M., 1996, Late Tertiary fluid migration in the Timor Sea.A key control on thermal and diagenetic histories?: The Australian Petroleum Production and Exploration Association Journal, v. 36, p. 399426.Patillo,J.,Nicholls,P.J., 1990, A tectonostratigraphic framework for the Vulcan Graben, Timor Sea region. The Australian Petroleum Production and Exploration Association Journal, v. 30 , p. $27-51$.

Patillo, J., Nicholls, P.J., 1990, A tectonostratigraphic framework for the Vulcan Graben, Timor Sea region. The Australian Petroleum Production and Exploration Association Journal, v. 30, p. 27-51.

Posamentier, H.W., Davies, R.J., Cartwright, J.A., Wood, L., 2007, Seismic geomorphology an overview. In: Davies, R.J., Posamentier, H.W., Wood, L.J., Cartwright, J.A., 2007, Seismic Geomorphology: Applications to Hydrocarbon Exploration and Production. Geological Society, London, Special Publications, v. 277, p 1-14. 
Posamentier, H.W., Jervey, M.T., Vail, P.R., 1988, Eustatic controls on clastic deposition. I. Conceptual framework. In: Wilgus, C.K., Hastings, B.S., Kendall, C.G.St.C., Posamentier, H.W., Ross, C.A., Van Wagoner, J.C. (Eds.), Sea Level Changes-An Integrated Approach, v. 42. SEPM Special Publication, p. 110-124

Posamentier, H.W., Laurin, P., Warmath, A., Purnama, M., and Drajat, D., 2010, Seismic stratigraphy and Geomorphology of Oligocene to Miocene Carbonate Buildups, Offshore Madura, Indonesia, in Morgan, W.A., George, A., Harris, P.M., Kupecz, J.A., and Sarg, J.F., eds., Cenozoic Carbonate Systems of Australasia, p. 175-192 SEPM Special Publication No. 95: Tulsa, Oklahoma, SEPM (Society for Sedimentary Geology).

Pratt, B.R., James, N.P., 1986, The St George Group (Late Ordovician) of western Newfoundland: tidal flat island for carbonate sedimentation in shallow epeiric seas: Sedimentology, v. 33, p. 313-343.

Pye, K., French, P.W., 1993, Erosion and Accretion Processes on British Salt marshes. Cambridge Environmental Research Consultants, Cambridge.

Rankey, E.C., Berkeley, A., 2011, Holocene carbonate tidal flats, p 507-535: in Davis Jr., R.A., Dalrymple, R.W., eds., Principles of Tidal Sedimentology, Springer,-Verlag, 621p.

Rankey, E.C., Morgan, J.J., 2002, Quantified rates of geomorphic change on a modern carbonate tidal flat, Bahamas: Geology, v. 30, p. 583-586.

Raymo, M.E., Mitrovica, J.X., O'Leary, M.J., DeConto, R.M., Hearty, P.J., 2011, Departures from eustasy in Pliocene sea-level records, Nature Geosciences, v. 4, p. 328-332.

Razin, P., Taati, F., Van Buchem, F.S.P., 2010, Sequence stratigraphy of CenomanianTuronian carbonate platform margins (Sarvak Formation) in the High Zagros, SW Iran: an outcrop reference model for the Arabian Plate: Geological Society, London, Special Publications, v. 329, p. 187-218.

Reijenstein, H.M., Posamentier, H.W., Bhattacharya, J.P., 2011,Seismic geomorphology and high-resolution seismic stratigraphy of inner-shelf fluvial, estuarine, deltaic, and marine sequences, Gulf of Thailand ,AAPG Bulletin, v. 95, p. 1959-1990

Rexilius, J.P., Islam, M.A., 1985, Biostratigraphic report and Source Rock Evaluation of Darwinia-1a, Bonaparte Gulf Basin, ECL Australia Pty. Ltd., Perth, WA, Australia, Well Completion Report, Geoscience Australia Data Repository, 44 p.

Saqab, M.M. and Bourget, J., 2015,Controls on the distribution and growth of isolated carbonate build-ups in the Timor Sea (NWAustralia) during the Quaternary: Marine and Petroleum Geology, v. 62, p. 123-143

Sarg, J.F., 1988, Carbonate Sequence Stratigraphy. In: Sea-Level Changes-An Integrated Approach: SEPM Special Publication No. 42. p. 155-181

Schlager, W., 2005, Carbonate Sedimentology and Sequence Stratigraphy. SEPM Concepts in Sedimentology and Paleontology Series no. 8, 200 p. 
Shuster, M.W., Eaton, S., Wakefield, L.L., and Kloosternan, H.J., 1998, Neogene tectonics, Greater Timor Sea, offshore Australia: Implications for trap risk: The Australian Petroleum Production and Exploration Association Journal, v. 38, p. 351-379.

Tcherepanov, E.N., Droxler,A.W., Lapointe, P., Mohn, K., Larsen, O.A., 2010, Siliciclastic influx and burial of the Cenozoic carbonate system in the Gulf of Papua: Marine and Petroleum Geology, v. 27, p. 533-54.

Van Andel, T.H., Veevers, J.J., 1967, Morphology and sediments of the Timor Sea.Bureau of Mineral Resources Geology and Geophysics Bulletin, v. 83, 173 p.

VanBuchem, F.S.P., Gerdes, K.D., and Esteban, M., 2010, Mesozoic and Cenozoic carbonate systems of the Mediterranean and the Middle East: stratigraphic and diagenetic reference models - an introduction: Geological Society, London, Special Publication, v. 329, p. 1-7.

VanBuchem, F.S.P., Razin, P., Homewood, P.W., Oterdoom, H., and Philip, J., 2002, Stratigraphic organization of carbonate ramps and organic-rich intrashelf basins: Natih formation (middle Cretaceous) of northern Oman: AAPG Bulletin v. 86, p. 21-54.

Veevers, J.J., 1971, Shallow stratigraphy and structure of the Australian continental margin beneath the Timor Sea: Marine Geology, v. 11, 209-249.

Whittam, D.B., Norvick, M.S., McIntyre, C.L., 1996, Mesozoic and Cenozoic tectonostratigraphy of western ZOCA and adjacent areas: The Australian Petroleum Production and Exploration Association Journal, v. 36, p. 209-232.

Wright, V.P., Burchette, T.P., 1996, Shallow-water carbonate environments, in Reading, H.G., ed., Sedimentary Environments: Processes, Facies, Stratigraphy, Oxford, Blackwell, p. 325-394.

Yokoyama, Y., DeDeckker, P., Lambeck, K., Johnston, P. \& Fifield, L. K., 2001a, Sea-level at the Last Glacial Maximum: evidence from northwestern Australia to constrain ice volumes for oxygen isotope stage 2: Palaeogeography Palaeoclimatology Palaeoecology, v. 165, p. 281-297.

Yokoyama, Y., Lambeck, K., DeDeckker, P., Johnston, P. \& Fifield, I.K., 2000, Timing of the Last Glacial Maximum from observed sea-level minima: Nature, v. 406, p. 713-716

Yokoyama, Y., Purcell, A., Lambeck, K., Johnston, P., 2001b, Shore-line reconstruction around Australia during the Last Glacial Maximum and Late Glacial Stage: Quaternary International, v. 83-85, p. 9-18.

Zampetti, V., Schlager. W., Van Konijnenburg, J.H., Everts, A.J., 2004, Architecture and growth history of a Miocene carbonate platform from 3D seismic reflection data; Luconia province, offshore Sarawak, Malaysia: Marine and Petroleum Geology, v.21, p. 517-534.

\section{VITAE}

S. Courgeon - Marine Geosciences Unit, Ifremer, France simon.courgeon@gmail.com 
Simon Courgeon works as a $\mathrm{PhD}$ candidate in the Marine Geosciences Unit of Ifremer. His

\section{CAPTIONS}

Figure 1: (A) Location map and physiography of the Bonaparte Basin (NW shelf, Australia). The blue colors (light to dark) correspond to the deepest bathymetry $(100-2000 \mathrm{~m}$ water depth), green colors correspond to the shallow bathymetry $(0-100 \mathrm{~m}$ below present sea level), the blue bold line represents the coastline and the yellow colors the continental area. The location of the Malita ISB isindicated by the red dashed line. The black polygon represents the Malita 3D seismic data set. Grey lines correspond to the 2D seismic data used in this study. The red cross corresponds to the Darwinia-1A exploration well. (B) Simplified tectonic setting of SE Asia (redrawn from Keep et al. 2007), the grey shaded areas correspond to the continental platforms $(<120 \mathrm{~m}$ water depth).

Figure 2: modern bathymetry of the 3D seismic area derived from the time structure map of the sea bed horizon. Water depth (in $\mathrm{m}$ below present sea level) has been converted from seismic TWT using a water 
seismic sections dd' and ee' are presented on Figures 4 and 6, respectively. White boxes show the location of the maps showed in Figures 7, 8 \& 13-20.

Figure 3: Interpretation of seismic facies based on the description and analysis of seismic geometries, reflection, configuration, continuity and amplitude strength. Interpretations are also based on seismic geomorphologies. TWT means Two Way Time.

Figure 4: Seismic stratigraphy of the Malita ISB on the seismic cross-section d-d' (location on Figure 2). (A) uninterpreted seismic profile showing the location of Figures $5 \mathrm{~A}$ and $5 \mathrm{~B}$ and the distribution of seismic facies; (B) interpreted seismic profile showing the three seismic unconformities D1, D2 and D3 highlighted by their stratal terminations (red arrows) showing downlaps, truncations, and onlaps. These unconformities are bounding two depositional units (Unit A and B). Note the presence of velocity pull-ups (V-P.U) beneath carbonate platforms as well as the seabed multiple.

Figure 5: Seismic stratigraphy of the Malita ISB (see location on Fig. 4). Stratal terminations (onlaps, downlaps and truncations) are indicated by the black arrows. The left panel (A) shows a close up on carbonate platform which was buried in Unit B (above D2). The right panel (B) shows a close up on a carbonate platform which was partially buried in Unit B and above which only small, isolated build ups developed. Seismic facies illustrations are indicated by red straight lines.

Figure 6: Composite seismic profile crossing the study area from the north-western edge of the intra-shelf basin to its centre. In Unit B the carbonate platforms of the ISB center were progressively drowned and buried while the carbonate aggradation continued along its shallower-water edges. Modern water depths are indicated. Location of area is shown on Figure 2.

Figure7: Perspective views (A and B) of RMS amplitude maps of the carbonate platforms along the unconformity D1 (A) and along a random horizon in Unit A (B) in the Malita ISB centre. Red and dark colors represent high and low amplitudes, respectively. Panel (A) highlights the incised geomorphology (fluvial or tidal channels) present along D1 at the base of Unit A. In panel (B) the carbonate platforms have aggraded and are at places separated by inter-platform seaways. Tide-dominated incisions have developed in the lower areas in between the carbonate platforms (within the seaways and in the ISB center). Location of area is shown on Figure 2. 
Figure8: Perspective views (A and B) of RMS amplitude maps of the carbonate platforms along the unconformity D2 (A) and along a random horizon in Unit B near the seabed (B) in the Malita ISB center. Red and dark colors represent high and low amplitudes, respectively. In panel (A) the carbonate platforms have reached their maximum size and fluvial channels develop in the center of the ISB. In panel (B) the carbonate platforms have significantly reduced in size as a result of backstepping and partial burial (Unit B). They are restricted to smaller, isolated build-ups. Location of area is shown on Figure 2.

Figure 9: Coherency attribute map draped over RMS amplitudes showing the paleogeography of the Malita ISB along the unconformity D2 (A) and the seabed (B). Red and dark colors represent high and low amplitudes, respectively. Note the backstepping and partial burial of the carbonate platforms between D2 and the present day seabed (Unit B).

Figure10:2D seismic line showing the location of the well Darwinia-1A and the Neogene seismic stratigraphy of the intra-shelf basin. See location on Figure 1.

Figure 11: Borehole geophysical (gamma-ray), lithology and stratigraphy log of the exploration well Darwinia-1a compiled from the well completion report. Biostratigraphy data is from Rexilius and Islam (1985). Nannoplankton subdivision from Martini (1971). See location on Figure 15.

Figure12: Internal architecture of the inter-platform seaways observed on composite seismic cross sections aa', bb' and cc' (See location on Figure 2). The inter-platform seaways form long-lived features (remaining in a stable position throughout Unit A) associated with a complex internal architecture showing repeated incisions and filling phases and dominantly high seismic amplitudes. The inter-platform seaways are interpreted as areas of increased current velocity when the platforms are flooded $\left(4^{\text {th }}\right.$-order sea level rises and highstands) in Unit A. The seaways are filled with sediments in Unit B as most carbonate platforms of the ISB center get progressively buried.

Figure13: : Inter-platform seaways observed on perspective view of RMS amplitude map of a random horizon in Unit A cut by an arbitrary seismic line. RMS amplitude map reveals the presence of smaller (tidal and/or fluvial) incisions along the paleo-valley floor of the seaways (green and yellow colors indicate higher amplitudes) and thought to form during the high-frequency (4th order) lowstands in Unit A. 
Figure14: Reflection amplitude extraction along a random horizon in Unit $A$ (above D1), showing different kinds of tidal channels and associated tributaries in the basin center and between the carbonate platforms . These geomorphologies imply periods of lower sea levels and near platform exposure in Unit A, consistent with the high-frequency sea level record of the Late Pliocene and early Quaternary (Figure 21A). Location of area is shown on Figure 2.

Figure15: Reflection amplitude extraction along a random horizon in Unit A (below D2), showing different kind of tidal tributaries and associated main channels, tidal ponds and carbonate platforms geomorphologies . These geomorphologies imply periods of lower sea levels and near platform exposure in Unit A, consistent with the high-frequency sea level record of the Late Pliocene and Early Quaternary (Figure 21A). Location of area is shown on Figure 2.

Figure 16: Reflection amplitude extraction along the unconformities D2 showing carbonate platforms, fluvial (F) and undifferentiated (F/T) channels along the inter-platform seaways and in the ISB centre. Some of these channels are characterized by narrow meandering geomorphologies fed by dendritic tributaries typical of fluvially-incised valley systems. These geomorphologies indicate that D2 was associated with platform exposure.

Figure 17: Reflection amplitude extraction along the unconformities D3 showing isolated build-ups (ibu) that result from antecedent carbonate platform (D2, Figure 16) backstepping and burial. This image also show fluvial (F) channels geomorphologies in the ISB centre. Some of these channels are characterized by narrow meandering geomorphologies fed by dendritic tributaries typical of fluvially-incised valley systems. These geomorphologies indicate that D3 was associated with platform exposure.

Figure18: Perspective view of RMS amplitudes along the seismic unconformity D3 in the south-eastern corner of the 3D seismic survey showing a meandering channel and its tributaries, interpreted as a fluvialdominated incised valley in the center of the Malita ISB during a period of platform exposure. See Location on Figure 2.

Figure 19: Seismic sections (A) and $262 \mathrm{~ms}$ time slice (red dashed line; B) showing the seismic expression of a meandering channel and its tributaries, interpreted as a fluvial-dominated incised valley. The time slice roughly corresponds to the horizon D2 (Fig. 4). Note the deeper incision of the main valley in comparison to its tributaries The apparent amplitude reversal between the main valley (appearing in plan 
view with lower amplitudes, black colors) and its tributaries (higher amplitudes in plan view, white colors) is due to the time slice being extracted just above the main channel and cross-cutting the seismic reflections. (C) A possible modern analogue for this fluvial-dominated channel from the Leichhardt River catchment in the Gulf of Carpentaria, in NE Australia (image from Google Earth).

Figure 20: (A) Coherency attribute draped over the time structure map of D2 showing the absence of faulting in the Malita ISB; (B) Coherency attribute map of D1 showing evidences of sparse, WSW-ENE trend, normal faulting in the Malita ISB center (location on panel A); (C) Fault interpretation in cross section (location on panel A). While Unit A is affected by low-offset, normal faulting, Unit B does not present any evidences of fault activity.

Figure21: Global sea-level and estimated subsidence and accommodation fluctuations in the ISB centre during the Plio-Quaternary. (A) The black curve represents the high-resolution global seal level reconstructed from the oxygen isotope record (from Miller et al., 2005). The red (D1 \& D2) and black (D3) lines represent the depth (burial) curves of the surfaces D1, D2 and D3. These were plotted using (1) an estimated paleo-bathymetry of $0 \mathrm{~m}$ at their time of formation and $(2$ )the sediment thickness between each surfaces and the modern sea floor (MSF) corresponding to $\Delta D 1-D 2, \Delta D 2-D 3$ and $\Delta D 3-$-seafloor.The suffixes "ini." and "fin." stand for initial and final depths of each surface, respectively. Burial rates are approximated as the mean subsidence rates between D1-D2, D2-D3 and D3-present day. Depths and thicknesses were calculated from seismic data (using a constant velocity of $V p=1800 \mathrm{~m} . \mathrm{s}^{-1}$ ) in the deepest part of the ISB centre (measured point "MP" in panel B) corresponding to a modern bathymetry of 135m. (C) The accommodation curve (black) was computed by combining the global seal level data with the estimated subsidence rates. Mean estimated Accommodation Rise Rates (ARR) have been calculated using a simple linear regression between D1-D2 and D2-present day.

Figure 22: Schematic summary of the $3^{\text {rd }}$ order sequence stratigraphic evolution of Malita ISB centre during the Late Pliocene and Quaternary. Unit $A$ is interpreted as a $3^{\text {rd }}$-order transgressive sequence of Late Pliocene and Early to Middle Quaternary age. This unit is associated with an overall aggradation of the carbonate platforms in the Malita ISB above the early/Late Pliocene sequence boundary D1. Highfrequency sea level fluctuations resulted in repeated, $4^{\text {th }}$-order lowstands during which mainly tidal channel networks developed in between the carbonate platforms. Unit $B$ is also interpreted as a $3^{\text {rd }}$-order transgressive sequence of Late Quaternary age. This sequence is however associated with (1) much higher 
1241 rate of accommodation creation (renewed subsidence) at $3^{\text {rd }}$-order and; (2) increased input of siliciclastic

1242 sediments into the ISB center during the $4^{\text {th }}$-order, high-amplitude sea level lowstands of the Late

1243 Quaternary. This resulted in the backstepping, drowning and partial burial of carbonate platforms in the

1244 deepest part of the ISB centre. In this area, above the sequence boundary D2, carbonate production

1245 became restricted to small, isolated build-ups that developed on the highest point of the underlying

1246 carbonate platforms. These isolated build-ups are drowned (located at water depths $>100$ m) at present

1247 day.

1249 Figure 23: Schematic model of $4^{\text {th }}$-order depositional cycle of the Malita ISB during the Late Quaternary

1250 (Unit B). During this period the Malita ISB is associated with differential subsidence (e.g., higher 1251 subsidence in theISB centre than along its edges). The interplay between high-frequency, high-amplitude sea level changes and differential platform topography resulted in diachronous platform growth rates: (A) carbonate platforms grow along the edges of the ISB during $4^{\text {th }}$ order TSTs and HSTs, whereas the isolated build-ups of the ISB centre are drowned during HSTs and are active during TSTs and Falling Stage System Tracts (FSSTs). LSTs are marked by isolated build-ups exposure and clastic infill in the ISB centre. Blue arrows indicate relative sea-level changes. 


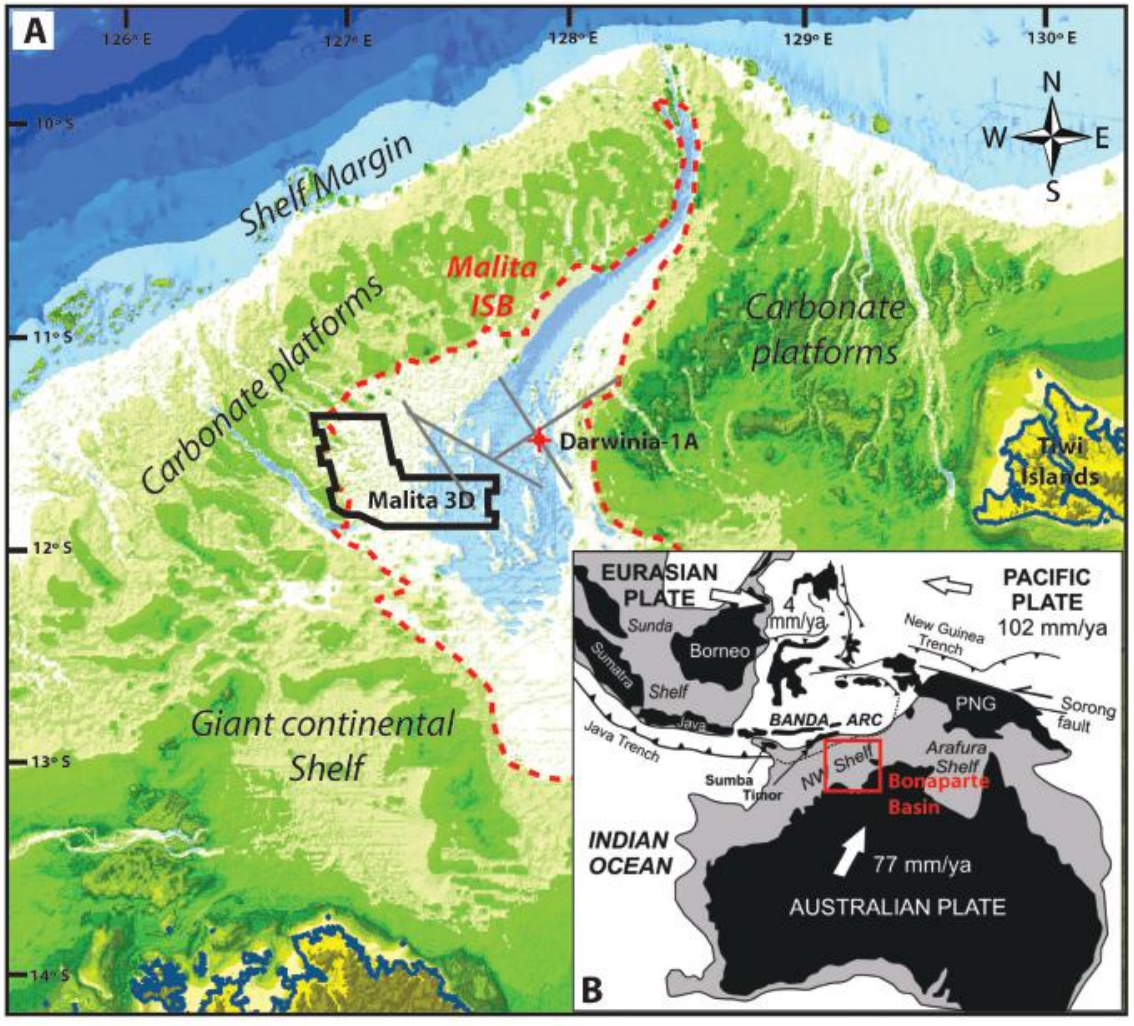




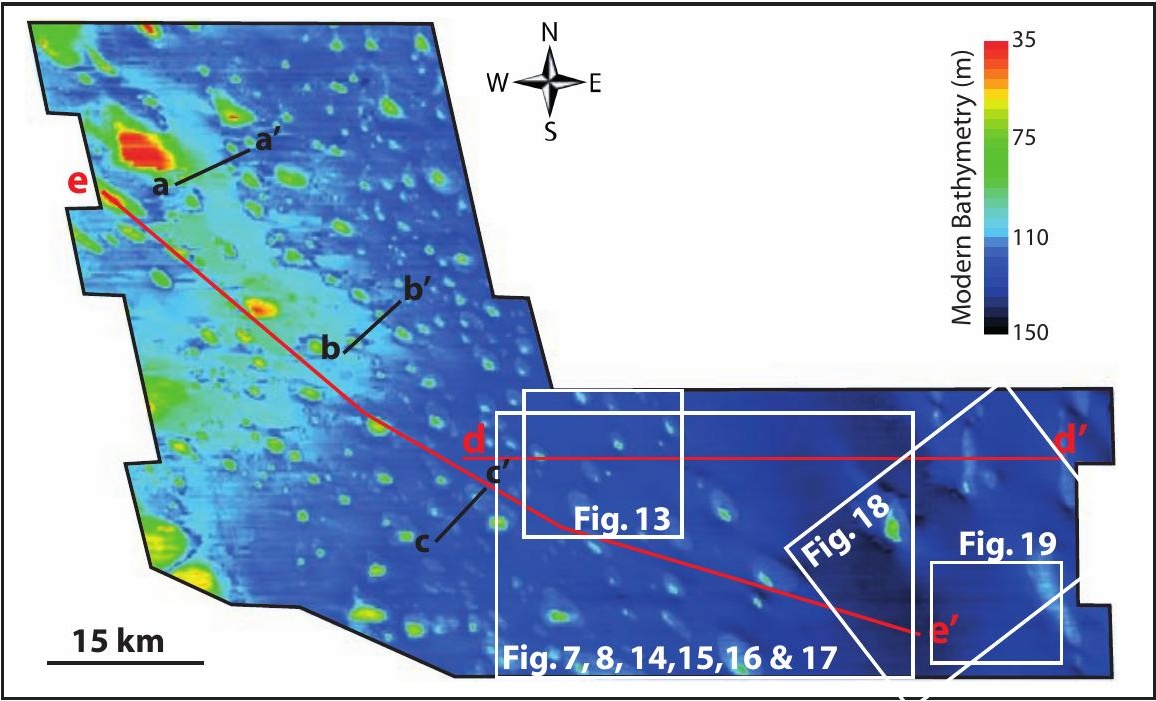




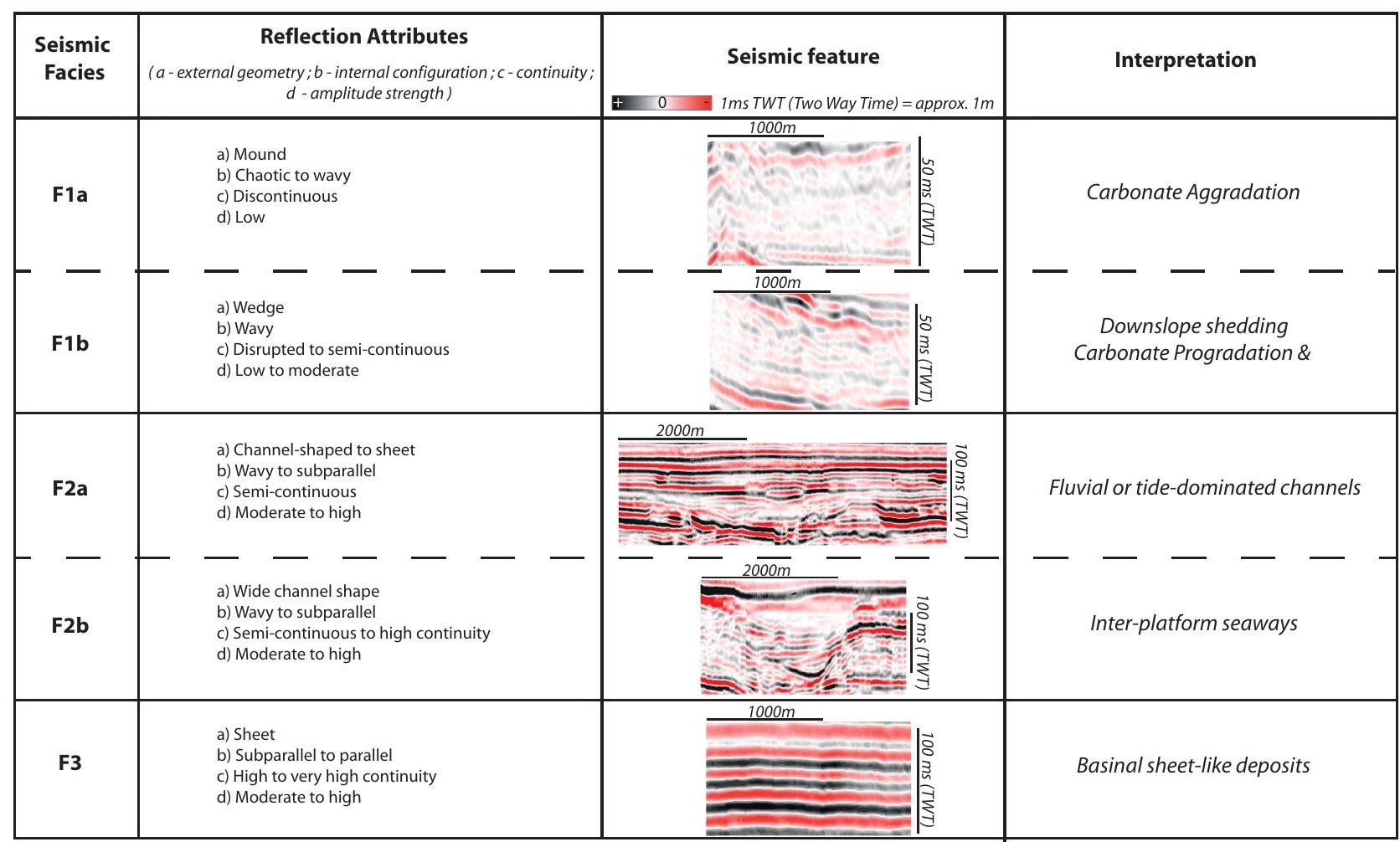




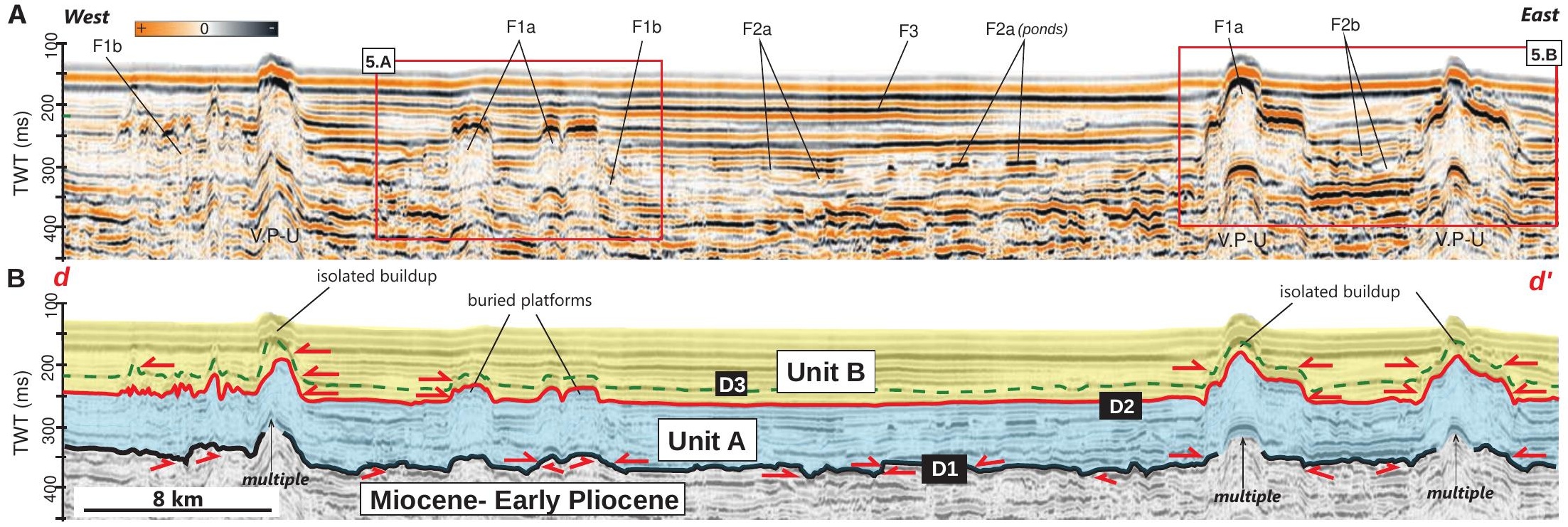




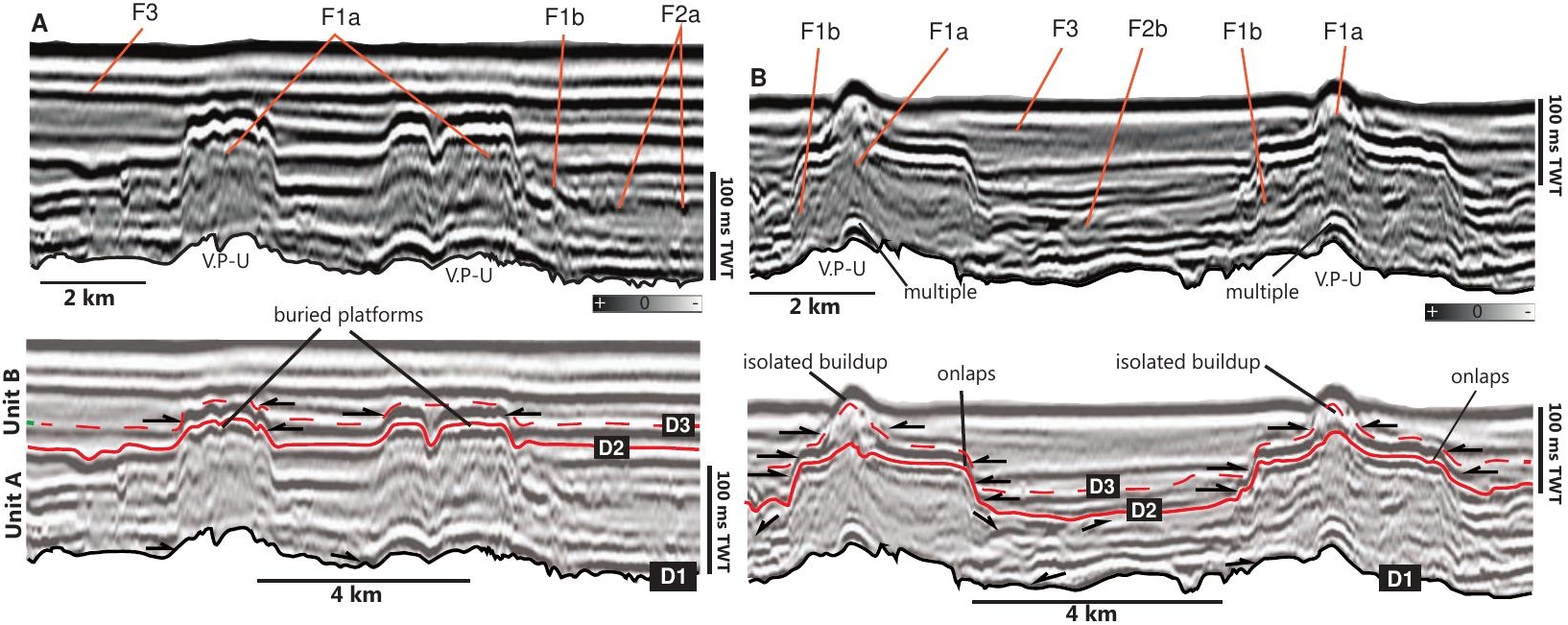


TWT NW platforms 


\section{Aggrading platforms Intra Unit A}

B

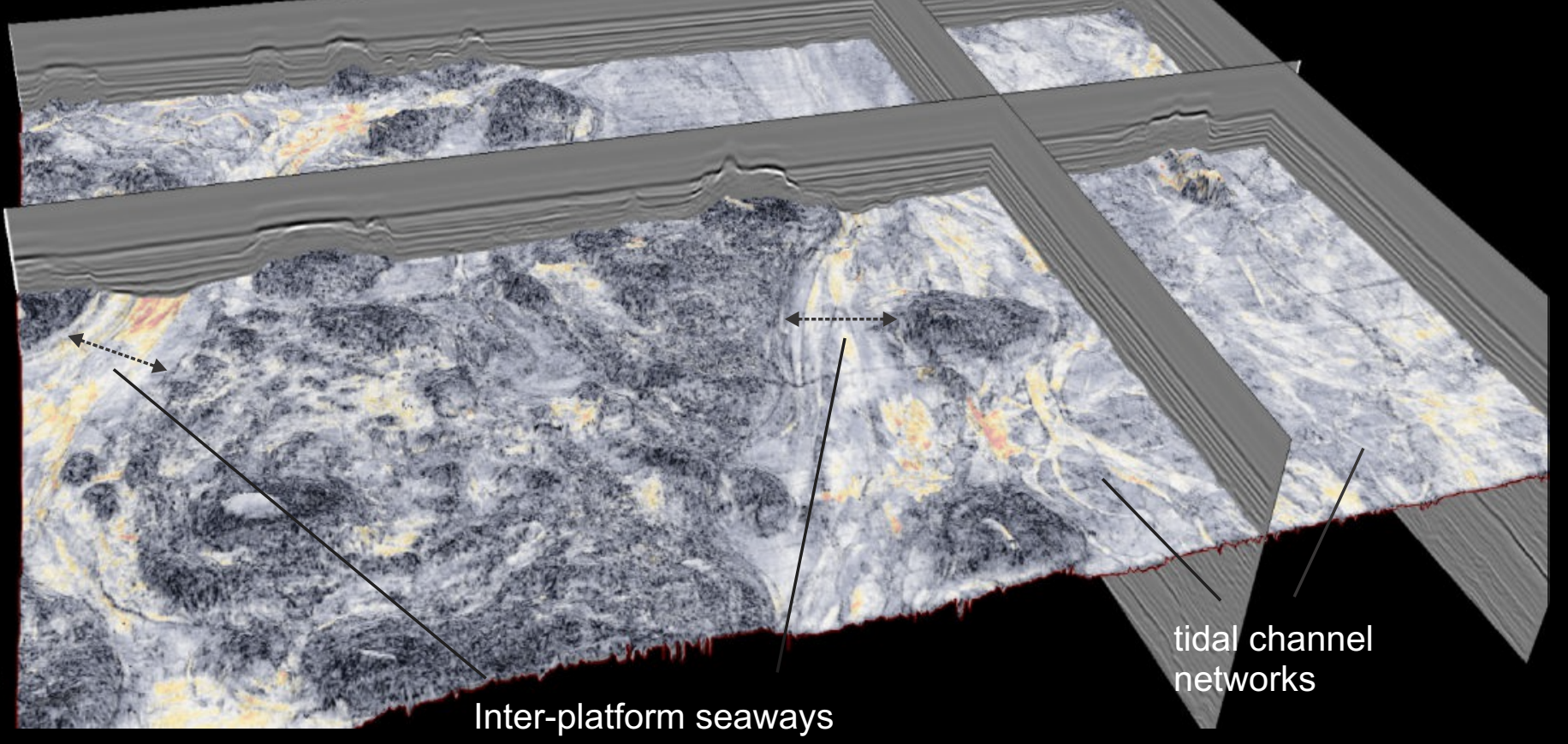

\section{Basal topography} D1
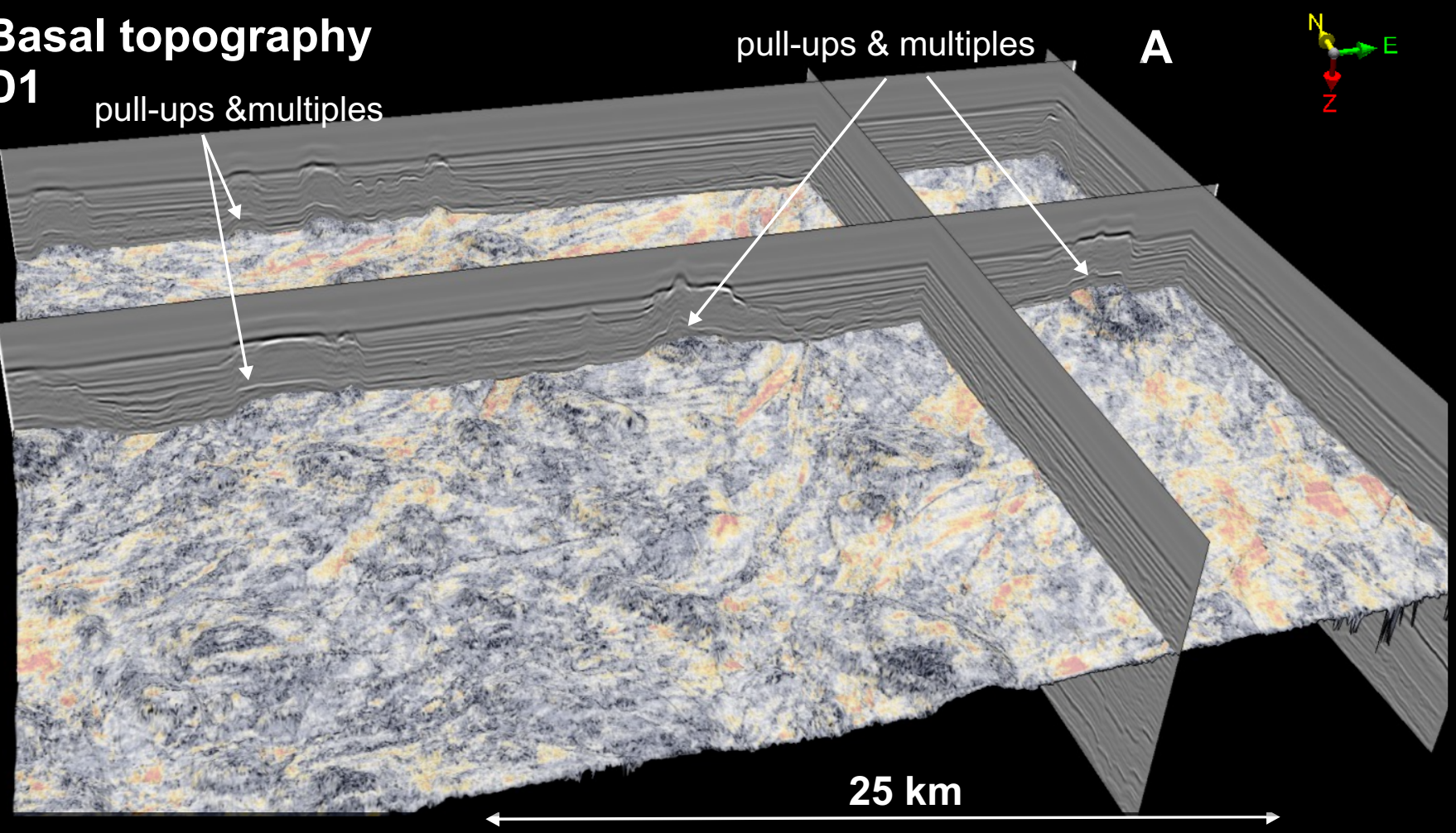
Backstepping isolated build-ups Partial burial

B Intra Unit B

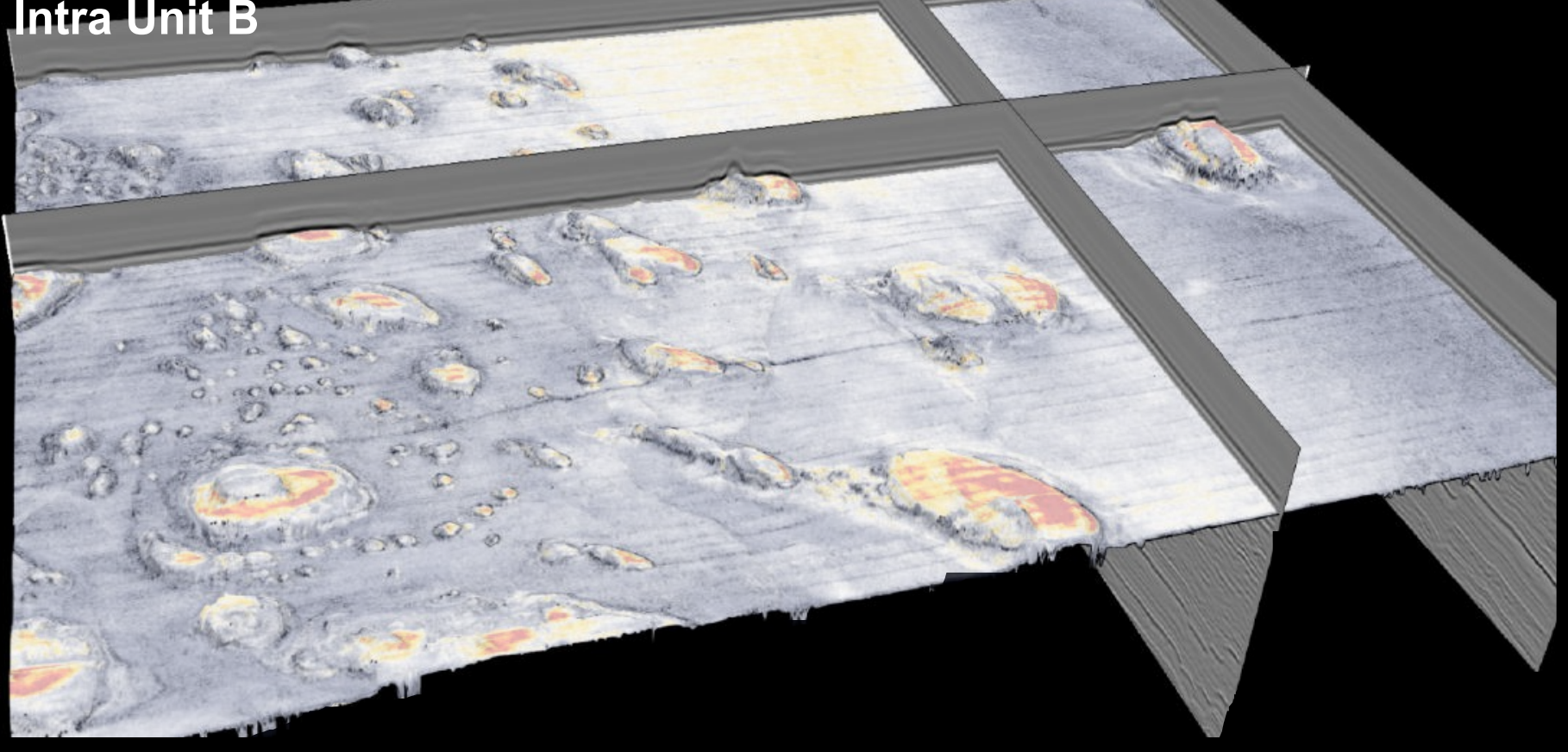

\section{Maximum platform growth}

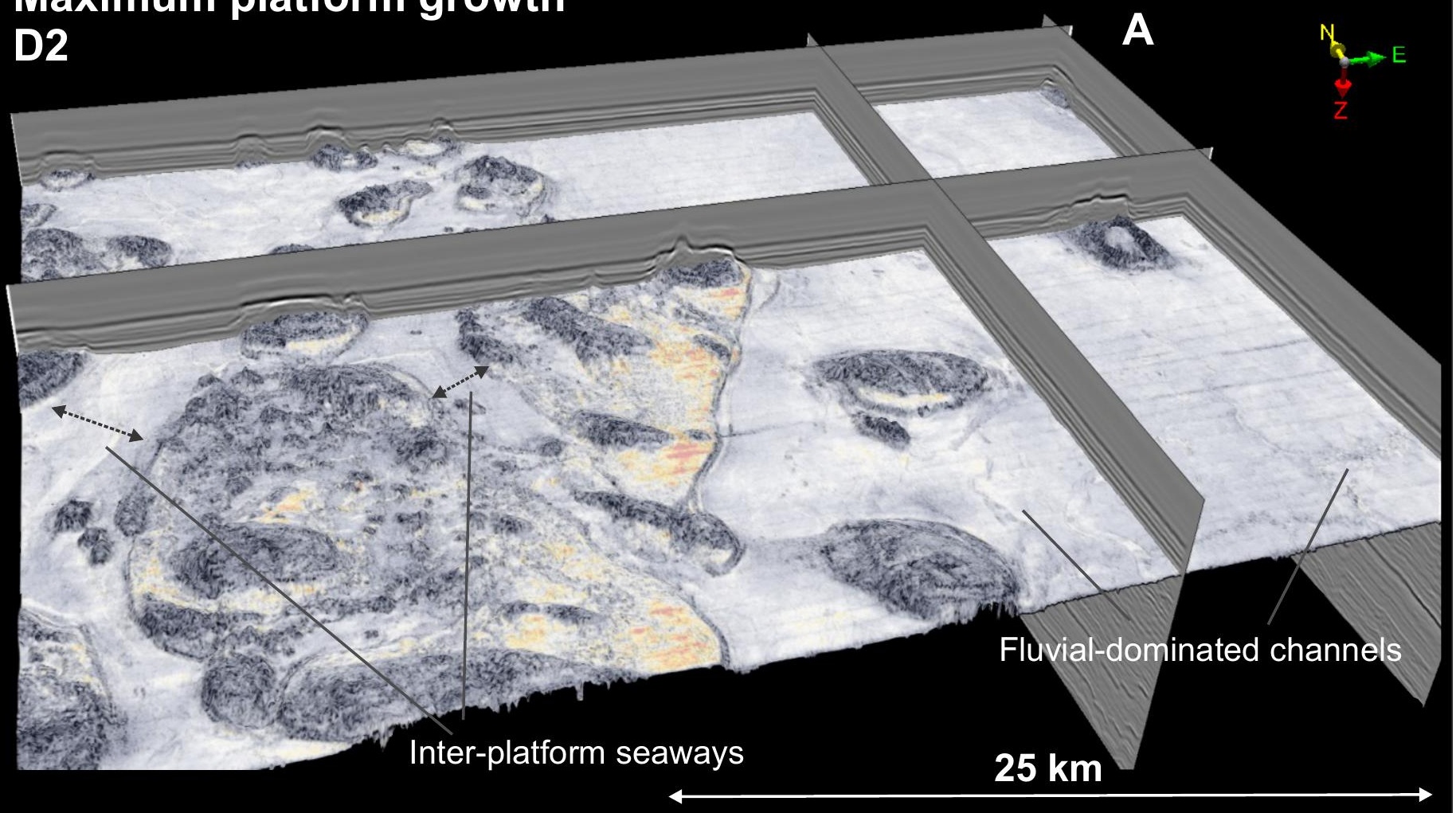


B prem

Shallow water platforms (ISB edge)

A
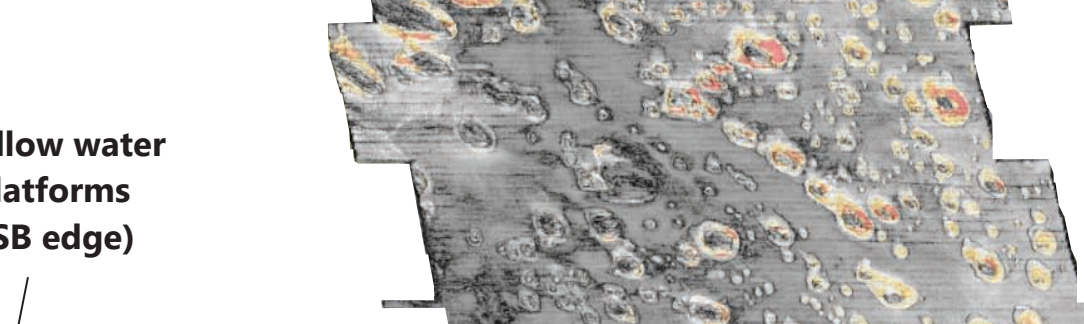

Isolated carbonate build-ups

\section{(6) (1) 4}
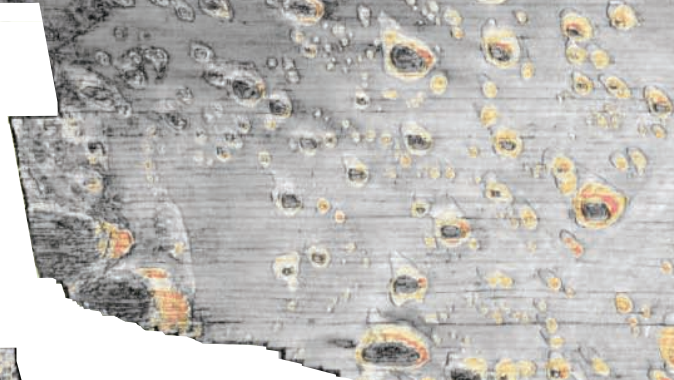

Carbonate platforms

(ISB centre)
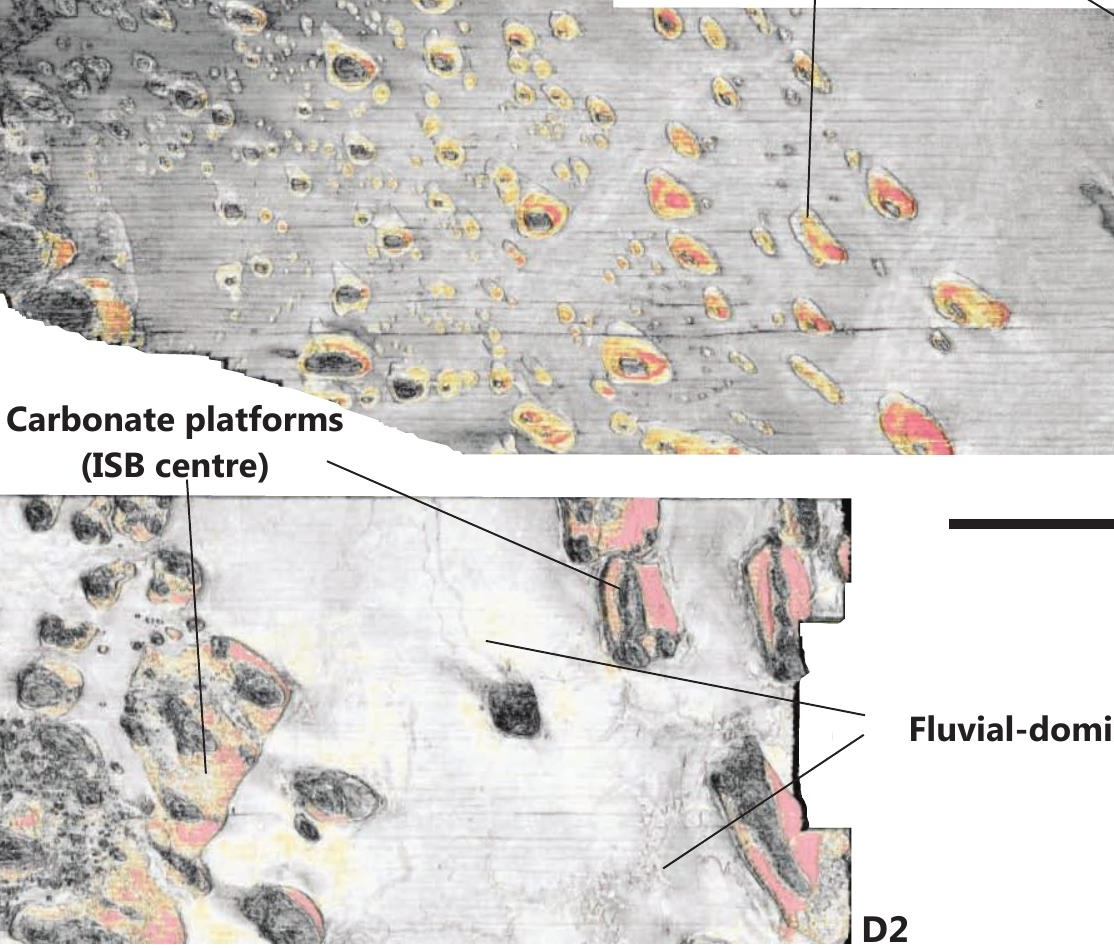

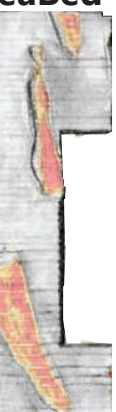

Norı

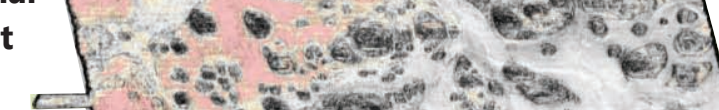

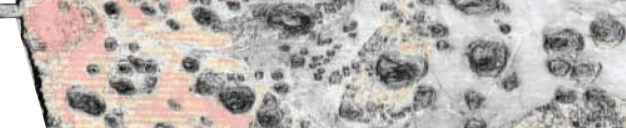

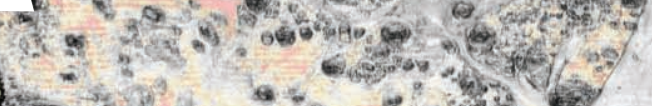

एist

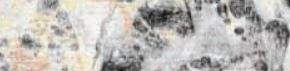

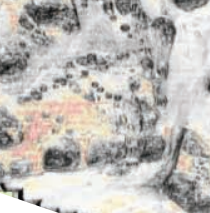




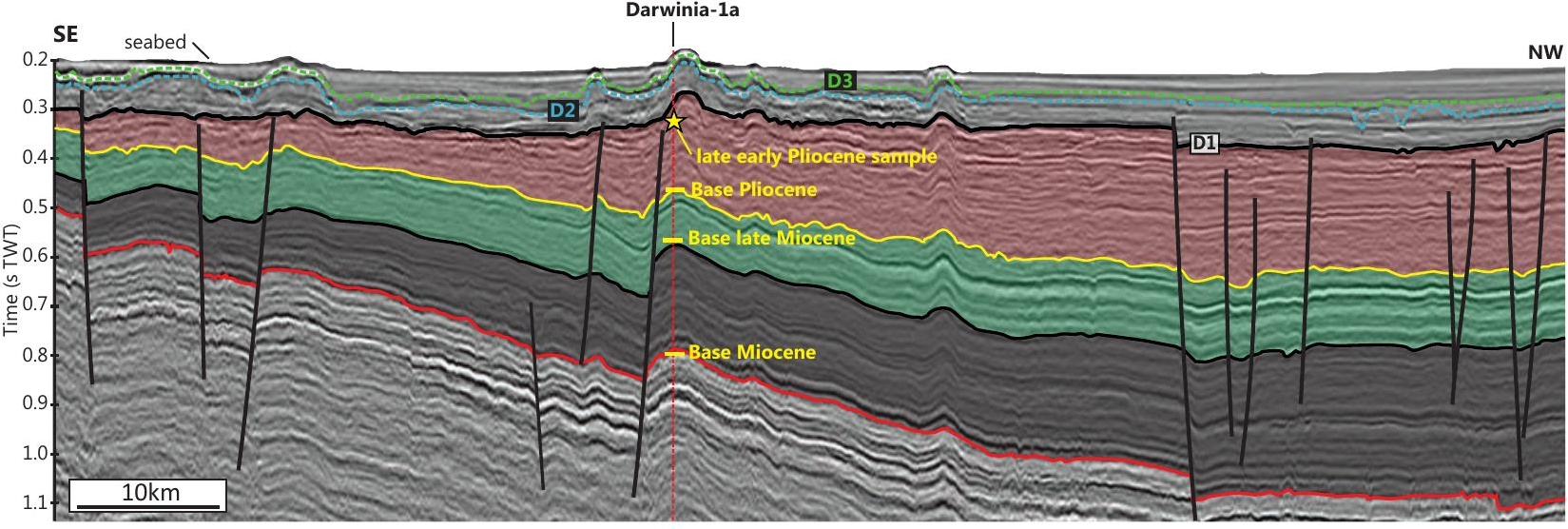


Darwinia-1a

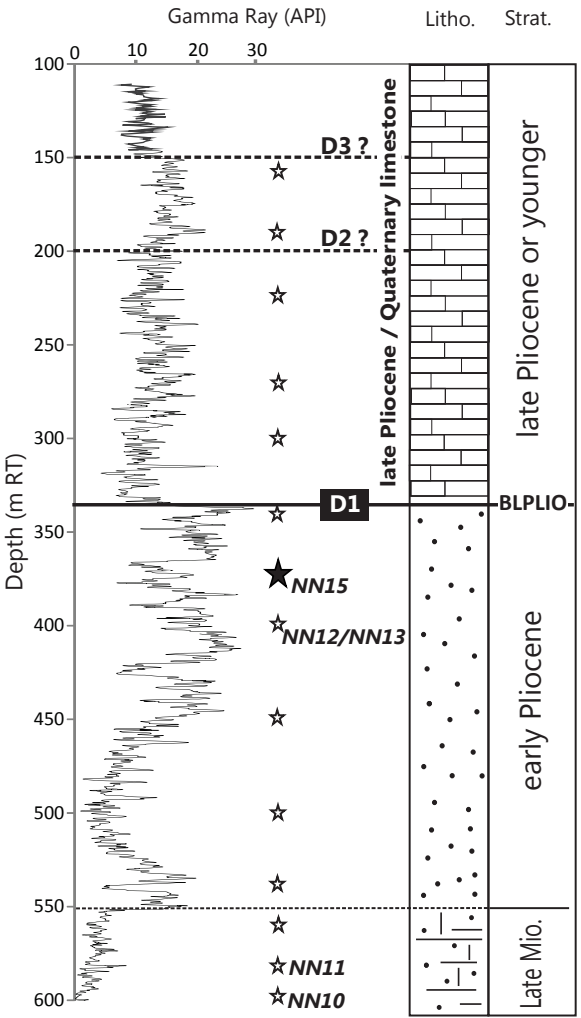

Key

$\star \quad$ Location of well cuttings (biostratigraphy / lithology)

Bioclastic limestone

Sandstone/limestone interbeds

Sandstone/mudstone with rare limestone 
Aggrading Inter-platform platform

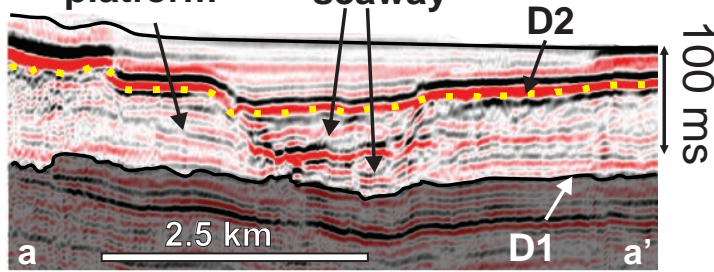

\section{Inter-platform Late Quaternary} seaway burial
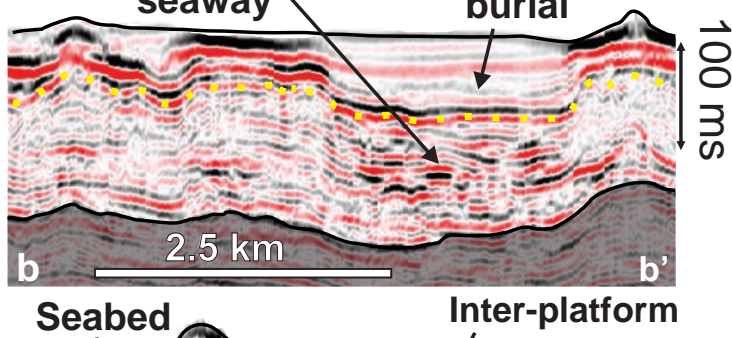

\section{$2.5 \mathrm{~km}$}

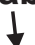




\section{Tidal channels}

within seaways

\section{Late Quaternary burial}




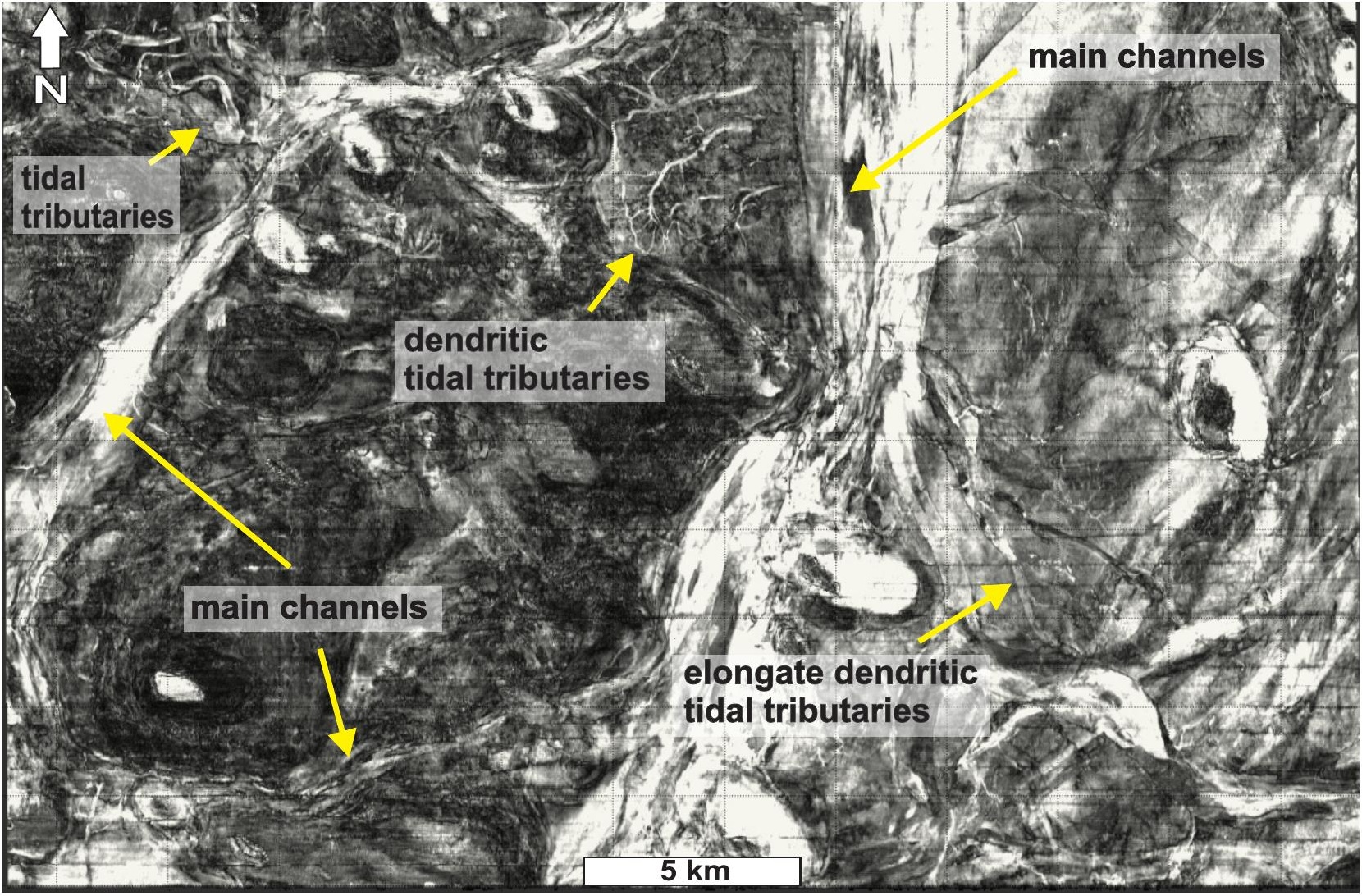




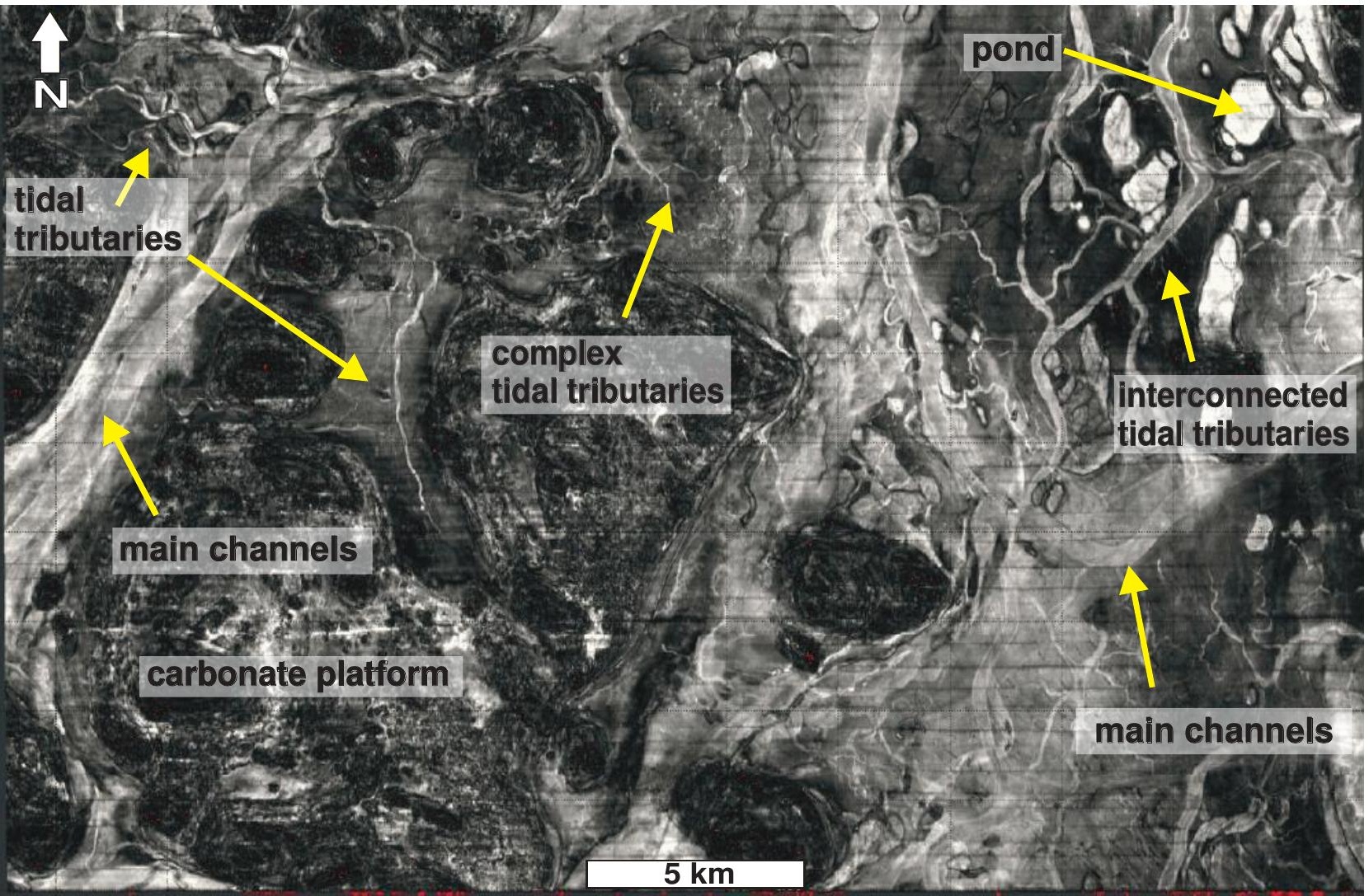




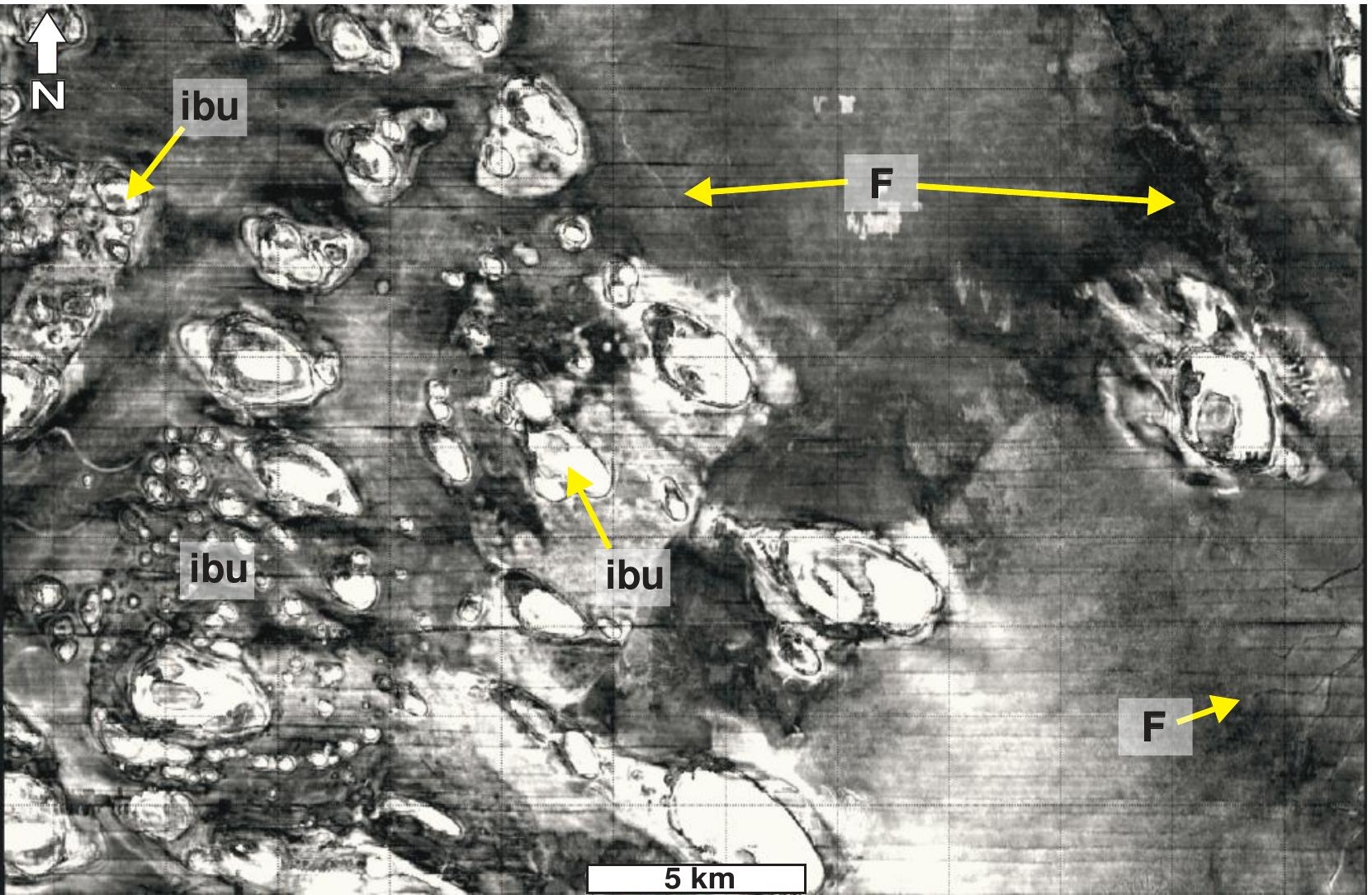




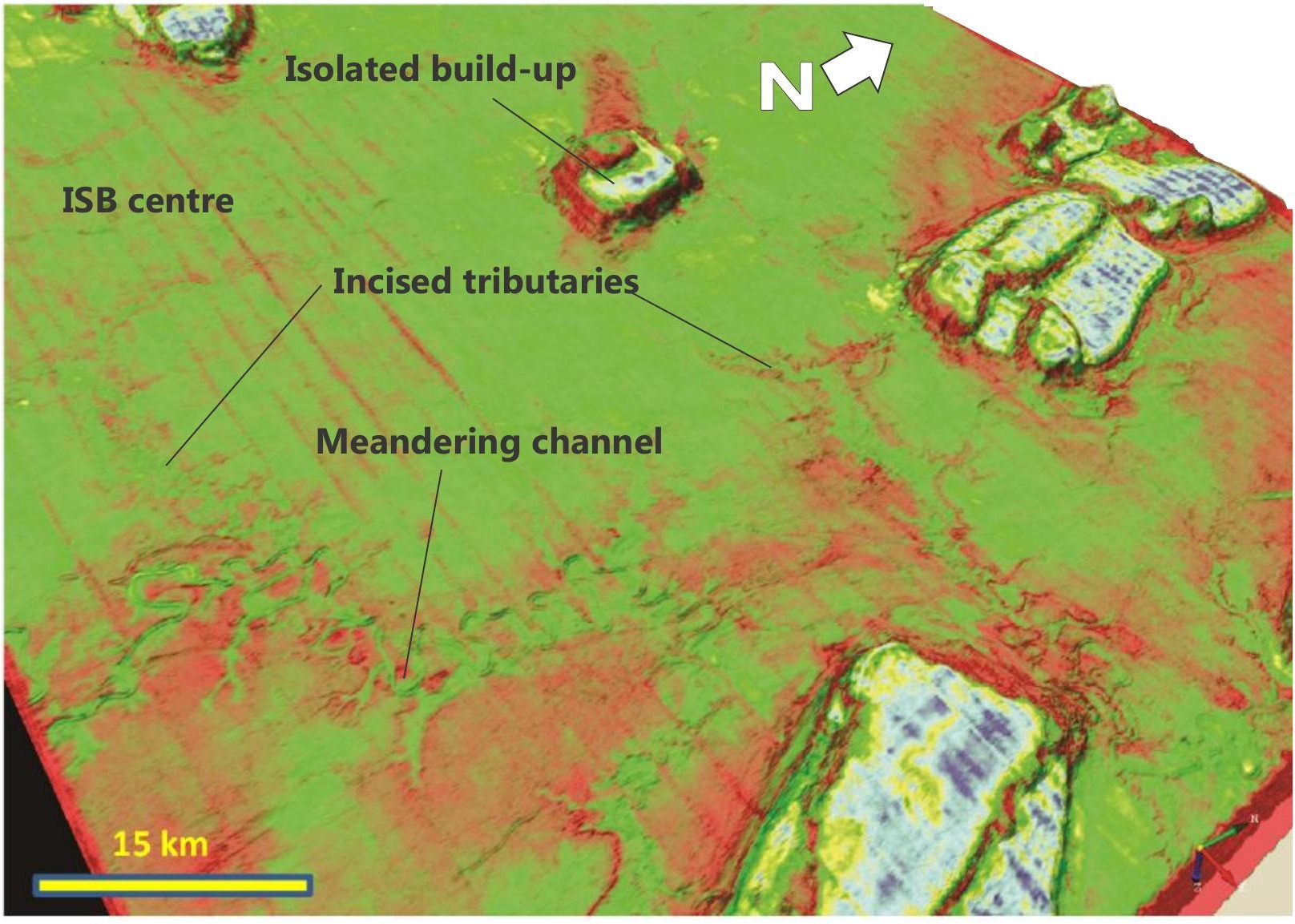




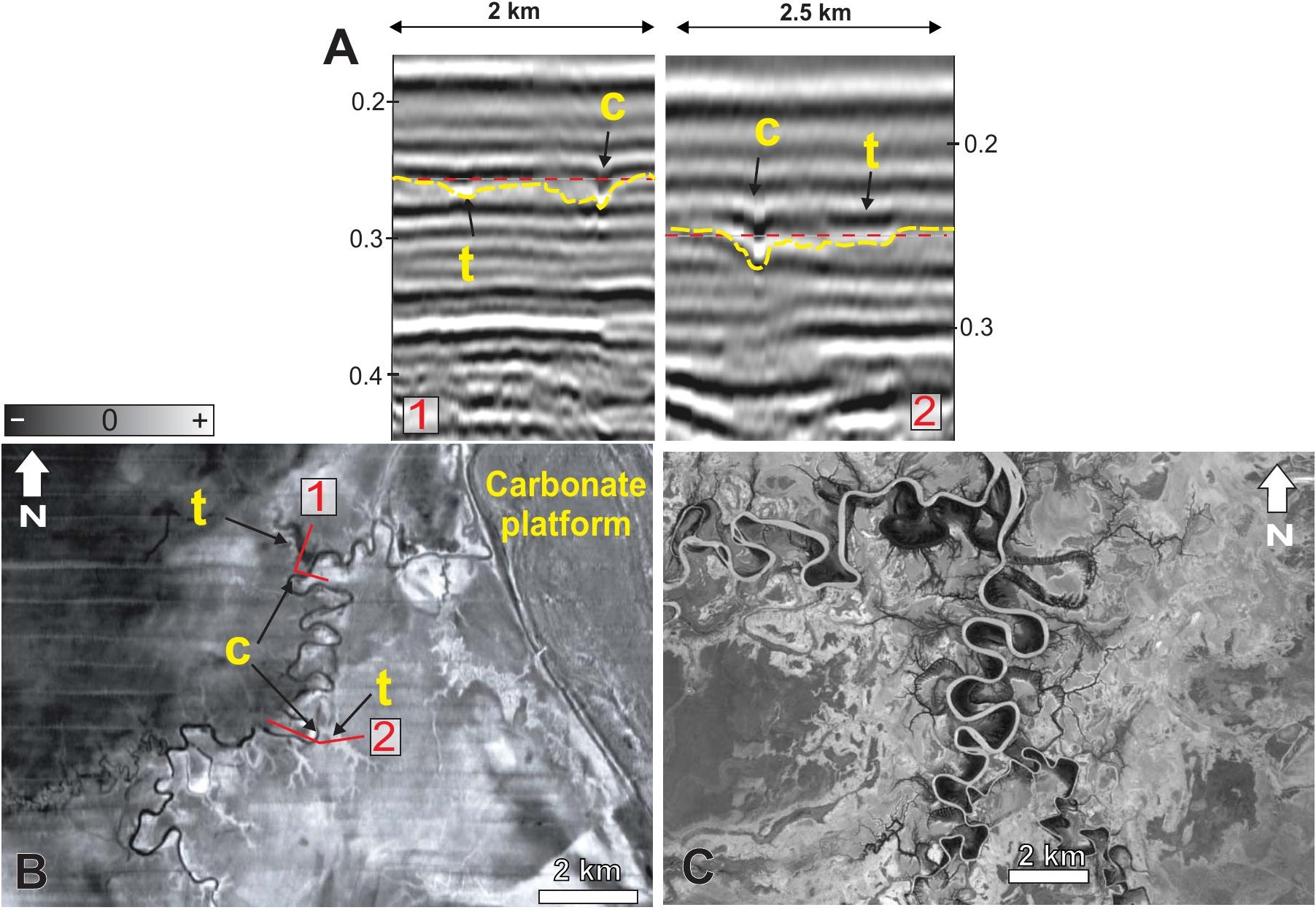


Late Pliocene and early-middle Quaternary (Unit A)

D1

$\mid$ Late Quat. (Unit B)
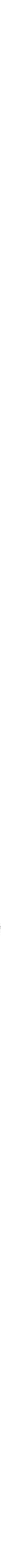


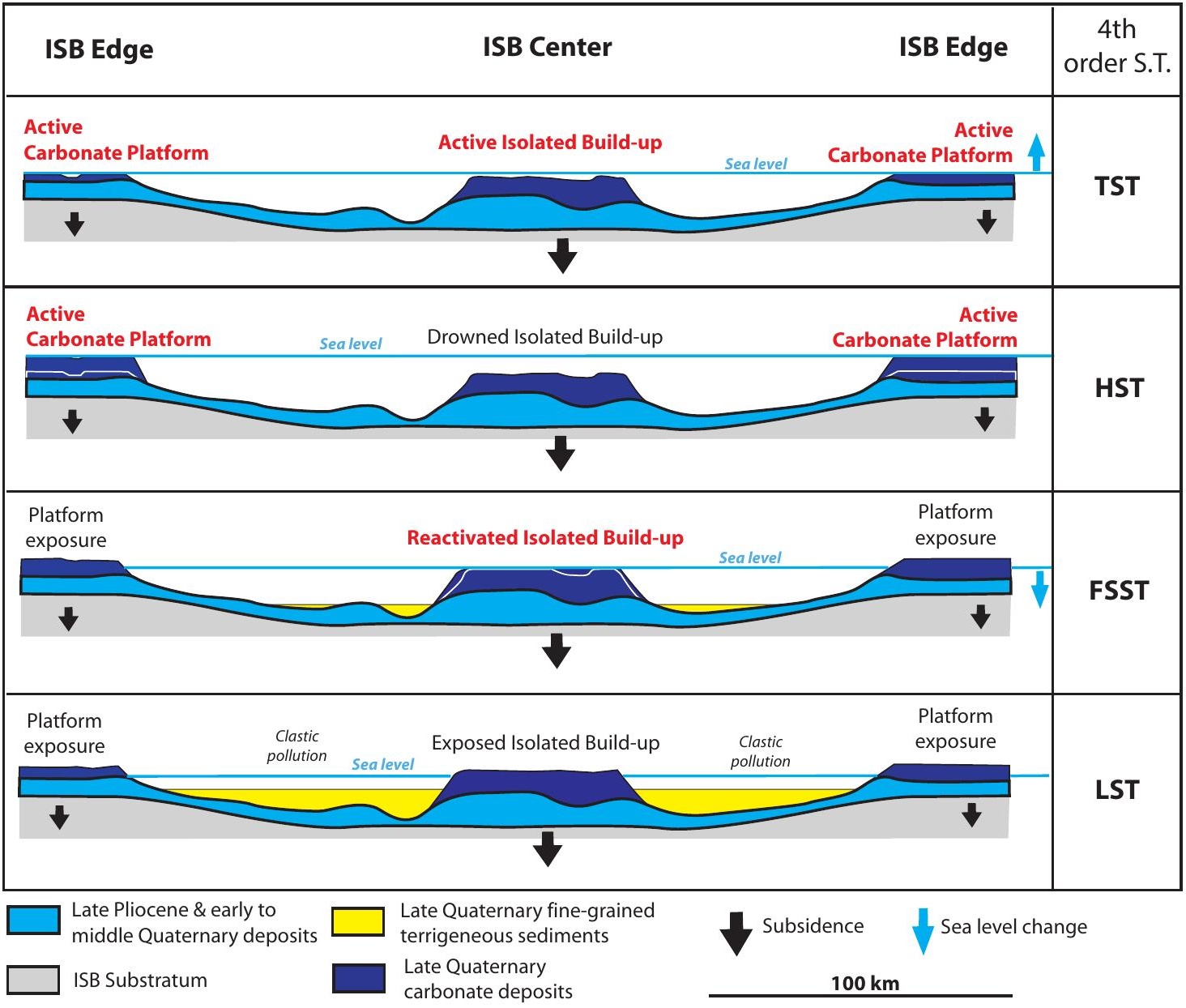

